Check for updates

Cite this: Chem. Commun., 2020, 56,9586

Received 30th April 2020,

Accepted 13th July 2020

DOI: $10.1039 / \mathrm{d} 0 \mathrm{cc} 03137 \mathrm{~b}$

rsc.li/chemcomm

\section{Proteins as diverse, efficient, and evolvable scaffolds for artificial metalloenzymes}

\begin{abstract}
Woo Jae Jeong, $\dagger$ Jaeseung Yu† and Woon Ju Song (DD *
By combining synthetic catalysts and biochemical tools, numerous artificial metalloenzymes have been designed to exhibit high catalytic activity and selectivity in diverse chemical transformations. Out of the nearly infinite number of discovered or characterised proteins, however, only a handful of proteins have been employed as scaffolds for artificial metalloenzymes, implying that specific proteins are preferred owing to their native structural, functional, or biochemical properties. In the present review, we extract and group the biochemical and structural properties of proteins that are advantageous in the design of artificial metalloenzymes; protein stability, pre-existing metal centre, native binding affinity for small molecules, confined and empty space, well-defined secondary structure, and native cellular location. The desirable properties highlight proteins as the key players in the design of metal-dependent biocatalysts. We also propose rarely considered, yet promising, proteins that could be versatile and unique scaffolds for novel metalloenzymes.
\end{abstract}

\section{Introduction}

The discovery of numerous metalloenzymes has inspired us to synthesize inorganic compounds that resemble the structure or function of the active sites. ${ }^{1,2}$ The design of biomimetic inorganic complexes often starts from the identification and construction of the active sites of natural enzymes, allowing for simplification of essential inorganic environments and evaluation of reaction mechanisms in catalysis. Unlike proteins, which have multiple amino acid residues comprising the active

Department of Chemistry, Seoul National University, Seoul 08826,

Republic of Korea.E-mail: woonjusong@snu.ac.kr

$\dagger$ These authors contributed equally to this work. sites, however, synthesis of multiple functional groups around the catalytic sites is often a great synthetic challenge. In this regard, reengineering proteins into artificial metalloenzymes might be viewed as an efficient route to understanding remarkably complex and tightly orchestrated actions of natural enzymes and to synthesise diverse metal-dependent biocatalysts. ${ }^{3-5}$

Recently, remarkable progress has been made in the design of artificial metalloenzymes that harbour inorganic cofactors or metal ions in the protein matrix. ${ }^{5-7}$ To design catalytically active units with only 20 canonical amino acids, well-defined hydrogen bonds, electrostatic, and/or hydrophobic interactions should be properly incorporated to accommodate a kinetically and thermodynamically tuned series of reactions during catalysis, which is not trivial even with our current state-of-the-art

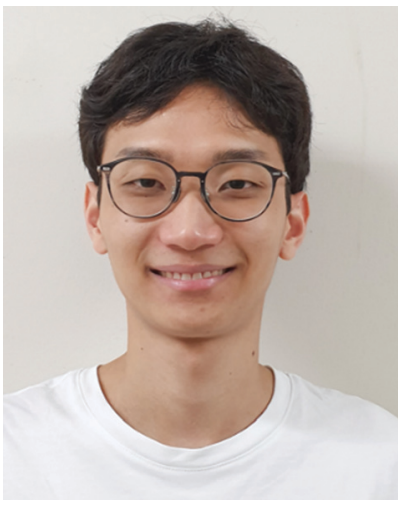

Woo Jae Jeong
Woo Jae Jeong earned a BS in Chemistry from Seoul National University in 2016 and is pursuing a PhD under the supervision of Professor Woon Ju Song. His current research topic is to design and evolve artificial metallo-hydrolases in novel protein scaffolds.

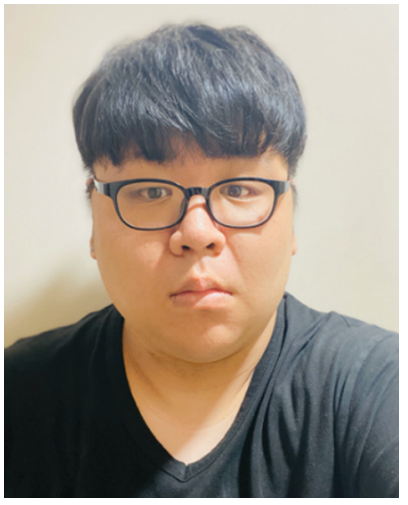

Jaeseung Yu received a BS in Chemistry from Kyungpook National University in 2016 and is pursuing a PhD in the Department of Chemistry at Seoul National University under the guidance of Professor Woon Ju Song. His current research topic lies in the controlled and efficient design and evolution of metallohydrolases. 


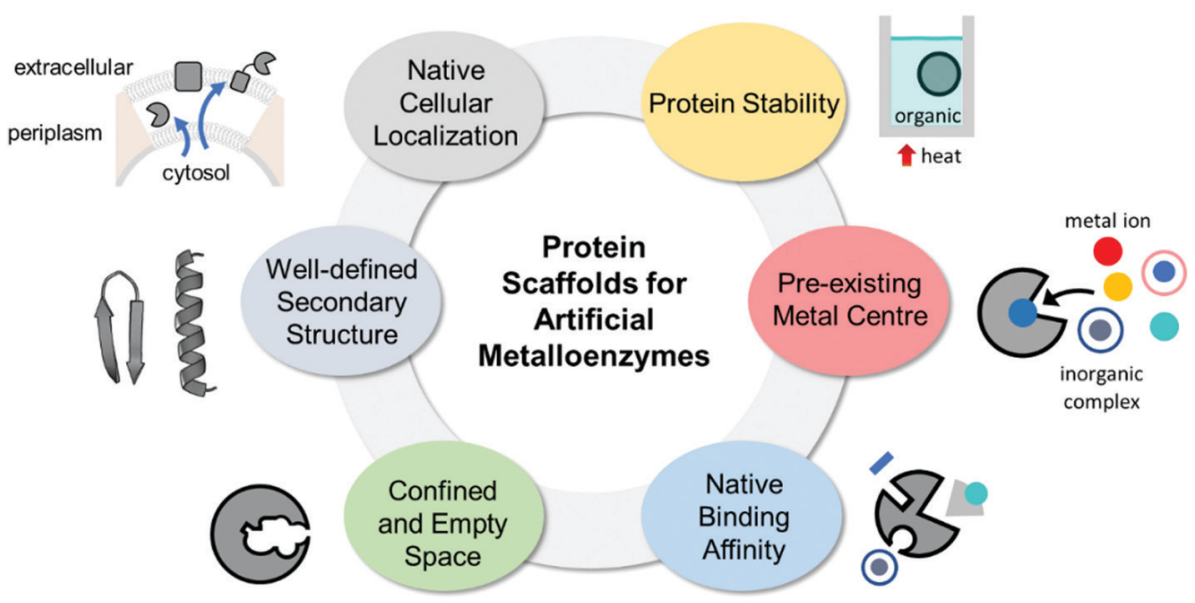

Fig. 1 The desirable properties of proteins as the scaffolds for artificial metalloenzymes.

in the understanding of protein sequence-structure-function relationships. In contrast, metal ions alone exhibit a wide range of nucleophilicity, electrophilicity, and/or Lewis acidity, giving rise to the basal requirements for catalytic reactivities upon complexation with appropriate ligands. In addition, metal ions possess multiple coordination numbers, providing vacant sites for substrate-binding. If metal elements are the key to resolving the great hurdle in the creation of catalytically active units, three questions arise in the design of artificial metalloenzymes: which chemical reactions to catalyse, how to introduce inorganic elements into proteins, and what protein scaffolds to start with? The first and second questions have been comprehensively covered in several reviews, ${ }^{8-11}$ whereas the last inquiry has not been explicitly discussed in detail.

As the ligand design is essential in biomimetic complexes and synthetic catalysts, the selection of proteins that function as metal coordination ligands and the locations for catalysis is critical in artificial metalloenzymes. In the present review, we highlight the specific protein scaffolds that have been

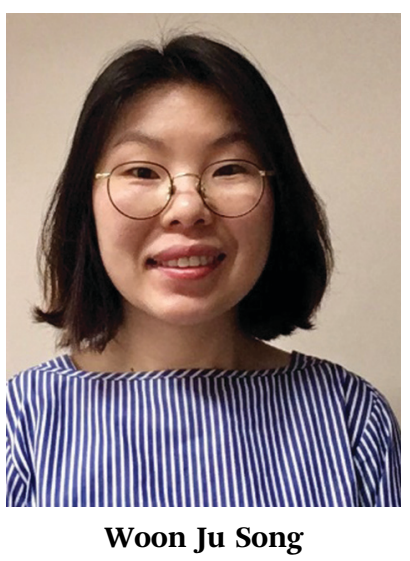

Woon Ju Song obtained her MS under the guidance of Professor Wonwoo Nam at Ewha Womans University and her PhD in the department of chemistry at MIT under the supervision of Professor Stephen J. Lippard. Then, she began her postgraduate studies in Professor Akif F. Tezcan group at the University of California, San Diego. Since she started her independent career at Seoul National University in 2016 as an assistant professor, her research group has been interested in the design and evolution of metalloproteins, protein self-assembly, and the discovery of novel proteins. effectively transformed into artificial metalloenzymes. Although some proteins are selected based on the method by which inorganic elements are introduced, several other factors should be carefully considered because the choice of a protein determines the structure and function of an artificial metalloenzyme. In addition, the protein scaffold provides unpredictable yet crucial properties that affect catalysis, such as protein expression yields, stability upon mutation, secondary coordination environments to inorganic centres, experimental conditions for activity assays, dynamic motion during catalysis, and evolvability. We have therefore assembled recent examples of artificial metalloenzymes based on the properties of their protein scaffolds. We then suggest additional properties of proteins for future studies to expand the scopes of artificial metalloenzymes.

\section{Considerations in the selection of protein ligands}

The properties of proteins adapted for novel metal-mediated catalytic activities are categorised into the following six factors: protein stability, pre-existing metal centre, native binding affinity, confined and empty space, well-defined secondary structure, and native cellular location (Fig. 1). These factors contribute to the successful transformation of naturally occurring proteins into nascent artificial metalloenzymes. Notably, successfully repurposed or designed protein scaffolds usually exhibit more than one of these factors, indicating that prior inspection of protein scaffolds is recommended for the efficient design of artificial metalloenzymes.

\subsection{Protein stability}

Proteins are often considered as unstable, delicate, and unpredictable ligands relative to synthetic ligands, which is a valid concern for applications, where non-physiological temperature, $\mathrm{pH}$, and organic solvents are often required. ${ }^{12}$ In addition, protein stability becomes even more essential in enzyme evolution because several rounds of mutation often lower protein stability by a trade-off for novel function. ${ }^{13,14}$ Fortunately, not every protein is unstable at 
Table 1 Stability of representative protein scaffolds adapted for artificial metalloenzymes

\begin{tabular}{|c|c|c|c|c|c|c|}
\hline \multirow[b]{2}{*}{ Protein (described section) } & \multirow[b]{2}{*}{ Host } & \multicolumn{2}{|l|}{ Thermal stability } & \multicolumn{2}{|c|}{$\underline{\mathrm{pH}}$ stability } & \multirow[b]{2}{*}{ Solvent condition $^{b}$} \\
\hline & & Highest temperature $\left({ }^{\circ} \mathrm{C}\right)$ & $\operatorname{Method}^{a}$ & $\mathrm{pH}$ range & Method $^{a}$ & \\
\hline Egg white lysozyme (2.1) & Gallus gallus & $74^{15}$ & $\mathrm{CD}$ & $3-12^{16}$ & FT-IR & \\
\hline Lipase, CAL-B $(2.1,2.3-2.4)$ & Candida antarctica & $54.8^{23}$ & DSF & $5-9^{24}$ & Activity & $100 \% \mathrm{DMF}^{22}$ \\
\hline $\operatorname{mTFP}^{*}(2.1,2.4 .1)$ & Clavularia & $87-90^{25}$ & $\mathrm{CD}$ & $2.3-12.3^{25}$ & $\mathrm{CD}$ & $60 \% \mathrm{DMSO}^{25}$ \\
\hline tHisF $(2.1,2.4 .1)$ & Thermotoga maritima & $95^{26}$ & Far-UV CD & & & \\
\hline pVIII coat protein $(2.1)$ & M13 bacteriophage & $75^{28}$ & CD & & & $98 \% \mathrm{DMSO}^{28}$ \\
\hline
\end{tabular}

${ }^{a}$ CD, DSC, DSF, and FT-IR represent circular dichroism, differential scanning calorimetry, differential scanning fluorimetry, and Fouriertransform infrared spectroscopy respectively. ${ }^{b}$ DCM, DMF, and DMSO indicate dichloromethane, $N, N$-dimethylformamide, and dimethyl sulfoxide, respectively.

nonbiological conditions (Table 1). Thermally stable and commercially available proteins, such as lysozymes ${ }^{15,16}$ and bovine serum albumin, ${ }^{17,18}$ have been adapted as feasible platforms on which to base catalytically active organometallic complexes such as a Grubbs catalyst (Fig. 2A) for ring-opening metathesis polymerisation ${ }^{19}$ or metal salts such as $\mathrm{K}_{2} \mathrm{OsO}_{2}(\mathrm{OH})_{4}, \mathrm{RuCl}_{3}$, and $\mathrm{Ti}(\mathrm{OMe})_{4}$ for dihydroxylation and epoxidation activity. ${ }^{20}$ Similarly, lipase has been frequently used for the generation of artificial metalloenzymes..$^{21,22}$ It is natively stable ${ }^{23,24}$ and commercially available so that covalent anchoring of a palladium pincer catalyst (Fig. 2B) resulted in catalytic activity for Heck cross-coupling. ${ }^{21}$ When immobilised on a sepharose support, lipase becomes durable even at high temperatures $\left(70{ }^{\circ} \mathrm{C}\right)$ and in the presence of organic solvents $\left(3: 1 \mathrm{DMF} / \mathrm{H}_{2} \mathrm{O}\right)$. Similarly, the integration of lipases with polymers yielded catalytic activity in the racemisation of $(S)$-1-phenylethylamine even at $55{ }^{\circ} \mathrm{C} .{ }^{22}$ Another protein, mTFP1 from Clavularia sp., was also selected owing to its temperature and
A

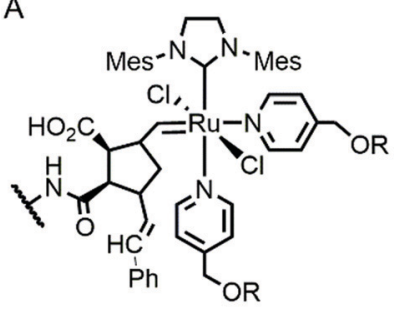

C

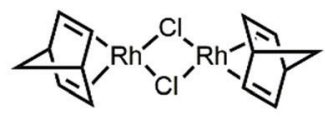

B

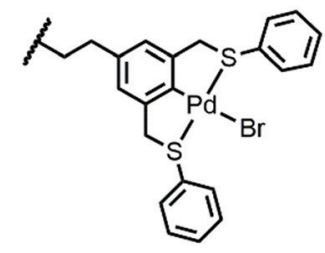

D

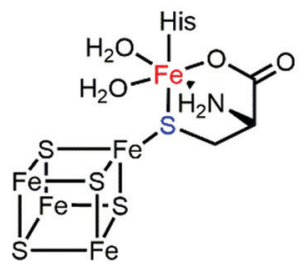

Fig. 2 The structures of representative inorganic complexes described in Sections 2.1 and 2.2. (A) Grubbs catalyst for ring-opening metathesis polymerisation, where $\mathrm{R}$ stands for poly(ethylene glycol). (B) Pd pincer catalyst for Heck coupling. (C) Di-Rh dinorbonadiene complex for phenylacetylene polymerisation. (D) $5 \mathrm{Fe}-4 \mathrm{~S}$ cluster in $\mathrm{HydG}$ in [FeFe]hydrogenase. The exchangeable $\mathrm{Fe}$ and $\mathrm{S}$ atoms are coloured in red and blue, respectively. The wavy lines in (a) and (b) indicate the anchoring point on the proteins.
pH stability. ${ }^{25}$ The addition of a Cu-binding site to the protein resulted in Diels-Alderase and Friedel-Crafts alkylase activities.

The necessity for thermal stability has led to the discovery of novel proteins in thermophilic organisms or bacteriophages (Table 1). For example, tHisF protein $^{26}$ from Thermotoga maritima was selected for asymmetric Diels-Alder reaction mediated by a mononuclear Cu-binding motif. ${ }^{27}$ In addition, an M13 bacteriophage pVIII coat protein was selected for Zn-dependent hydrolysis owing to its thermal stability, scalability, multi-valency, and ease of mutation. ${ }^{28}$ Therefore, these examples suggest that proteins with higher thermal stability are preferred to improve the feasibility of experiments and to expand the reaction to even harsh and non-physiological conditions.

For proteins for which stability have not been characterised, it would be useful to apply numerous in silico methods and simulation programmes. ${ }^{32}$ Applicable temperature ranges and alterations in melting temperature upon mutations can be predicted from protein sequence or structure, respectively. ${ }^{33-35}$

\subsection{Pre-existing metal centres}

One of the primary and long-standing methods to design novel metalloenzymes is to substitute inorganic elements, such as metal ions or metallocofactors, and/or to reshape the active site pockets. Then, natural metalloproteins that harbour pre-existing metal-active sites are the obvious starting materials for artificial metalloenzymes.

This efficient approach is applicable when apo-proteins are somewhat stable even after pre-existing metal ion/cofactors are chelated prior to reconstitution with novel inorganic elements. At least moderate binding affinity for metal ions and cofactors other than the native ones is also necessary for the preparation of artificial metalloproteins. Such metal promiscuity might sound counter-intuitive to the general understanding of natural enzymes as being highly selective for the specific metal ion to perform dedicated biochemical functions. It is, however, more prevalent than expected, ${ }^{11,36-38}$ and protein promiscuity, in fact, can lead to the appearance and divergence of novel enzymes. $^{39-41}$

To reconstitute metalloproteins, metal elements that favour similar inorganic environments to those of the native ones would be preferred, such as coordination number, geometry, 
and ligand properties (hard versus soft). The Metal-PDB database ${ }^{42}$ can be a valuable resource to search prevalent coordination geometry and ligands per each metal ion within proteinaceous environments. It is, however, worthy to note that proteins are flexible ligands, which may undergo multiple conformational changes and/or adapt alternative rotameric states depending on the neighbouring residues. Therefore, fine tailoring of proteins to construct novel metal-binding sites are still in great challenge.

Recent examples of replacing the native metal ions with novel ones have been carried out with structurally and spectroscopically well-characterised metalloenzymes (Fig. 3). A Cu in azurin (Fig. 3A) ${ }^{43}$ and Fe in rubredoxin (Fig. 3B) ${ }^{44}$ were replaced with $\mathrm{Fe}$ and $\mathrm{Ni}$ ion, yielding superoxide scavenging and hydrogenase activities, respectively. Notably, the $\mathrm{Cu}$ centre in azurin is a distorted trigonal bipyramidal geometry, which can be accommodated by Fe. Indeed, the Metal-PDB database indicates that $\mathrm{Fe}$ is the most prevalent metal element that replaces Cu-binding sites, followed by $\mathrm{Zn}$ ion. Similarly, the Ni-substituted rubredoxin was prepared presumably because such coordination geometry and the 4 cysteine ligands can be generated with $\mathrm{Ni}$, as observed in [NiFe] hydrogenase.

In addition, the structural resemblance between the native active sites and inorganic complexes can be adapted for repurposing metalloproteins. For example, a Mn-binding protein, TM1459 (Fig. 3C), was successfully reconstituted with an Os ion in its native metal centre. ${ }^{29}$ This work was initiated owing to the geometric resemblance of the active site to that of a previously characterised Os complex, Os-TPA (TPA = tris(2-pyridyl-methyl)amine). The chemo-mimetic enzyme exhibits peroxygenase activities with alkenes, resembling the catalytic activities of synthetic Os complexes. It is also worth noting that the enzyme activity assays were carried out at $70{ }^{\circ} \mathrm{C}$, which was possible because of the native thermal stability of the protein (Table 1). This example suggests that protein scaffolds that satisfy more than one desirable property would increase the scope of biocatalysis.

Multinuclear metalloenzymes such as ferritin have also been adapted for artificial metalloenzymes. The native $\mathrm{Fe}$ ions were replaced with di-Rh norbornadiene complexes (Fig. 2C), resulting in biocatalysts that polymerize phenylacetylene. ${ }^{45}$ It is worthy to note that the successful transformation of ferritin have gained the benefit of using not only the pre-existing metalcoordination motifs but also well-defined cavities within the protein cage as a reaction vessel for substrate-binding and/or the formation and tuning of novel reactive intermediates.

In addition to the substitution of metal ions, native inorganic cofactors have been replaced to create artificial metalloenzymes (Fig. 4). Haem proteins are by far the most extensively and effectively repurposed metalloprotein scaffolds for biocatalysts. $^{46-48}$ The native haem cofactors have been substituted with synthesised planar complexes such as Mn porphycene, ${ }^{49}$ $\mathrm{Ru}$ porphyrin, ${ }^{50}$ and Ir porphyrin complexes, ${ }^{51}$ catalysing $\mathrm{C}-\mathrm{H}$ activation, $\mathrm{N}-\mathrm{H}$ insertion of aniline, and enantio- and diastereoselective cyclopropanation of unactivated olefins, respectively (Fig. 4A). Notably, these transformations were carried out with a stable haem protein in the apo-state or with a protein from a thermophile, again, indicating that protein scaffolds that satisfy more than one of the listed criteria, such as protein stability, are beneficial to enzyme design.

Recently, the substitution of more complicated and delicate metallocofactors has also been carried out by either tailoring the native multi-enzymatic biosynthetic machinery or chemically modifying the native cofactors. [FeFe]-hydrogenase, or HydA1, for example, innately harbours an H-cluster, composed of four $\mathrm{CO}$, two $\mathrm{CN}^{-}$and a bridging dithiolate ligand between two Fe atoms. ${ }^{52}$ Because the metallocofactor is incorporated upon the action of a maturation enzyme, HydF, artificial hybrid hydrogenase HydA1 was prepared by pre-incubating a synthetic iron cluster analogues with HydF, followed by the addition of
A
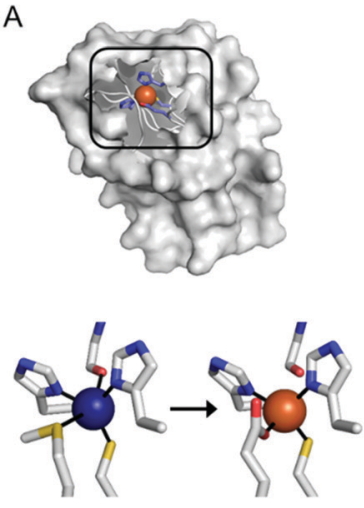

B
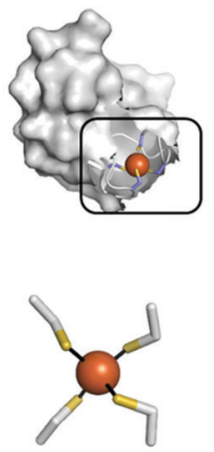

C
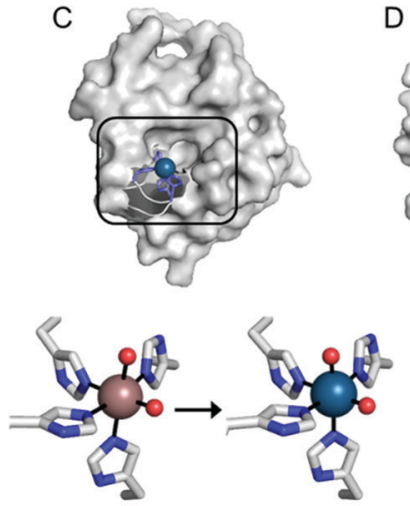

D
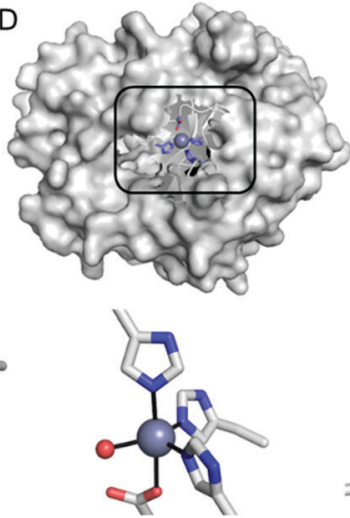

E
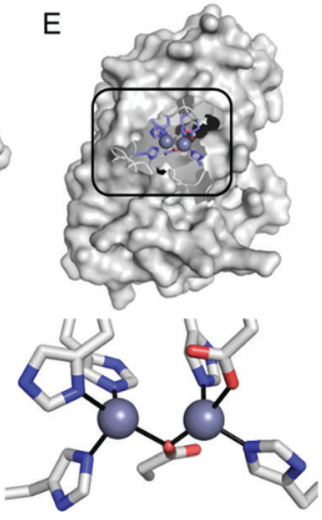

Fig. 3 Transformation of pre-existing metal-binding sites into the active sites of artificial metalloenzymes. (A) Fe ${ }^{2+}-\mathrm{Substituted}$ azurin (4QLW) from $\mathrm{Cu}^{2+}$-azurin (4AZU). (B) The wild-type rubredoxin with a Fe ${ }^{3+}$-centre (6RXN). (C) TM1459 substituted with an Os ${ }^{3+}$ complex (5WSF) from the native form with $\mathrm{Mn}^{2+}$-bound form (1VJ2). (D) $\mathrm{Zn}^{2+}$-Dependent phosphatase PT3.1 (3T1G) derived from adenosine deaminase. (E) The wild-type glyoxalase II complexed with $\mathrm{Zn}^{2+}$ ions (PDB 1QH5). In (a) and (c), the native metal coordination sites before the metal-substitution are depicted bottom left. PDB codes are given in parentheses. Metal ions and metal-ligating amino acids are depicted with spheres and sticks, respectively. $\mathrm{Cu}$, Fe, Mn, Os, and $\mathrm{Zn}$ atoms are coloured in navy, orange, purple, light blue, and light purple, respectively. Carbon, nitrogen, and oxygen atoms in metal-binding residues are coloured in grey, blue, and red, respectively. 


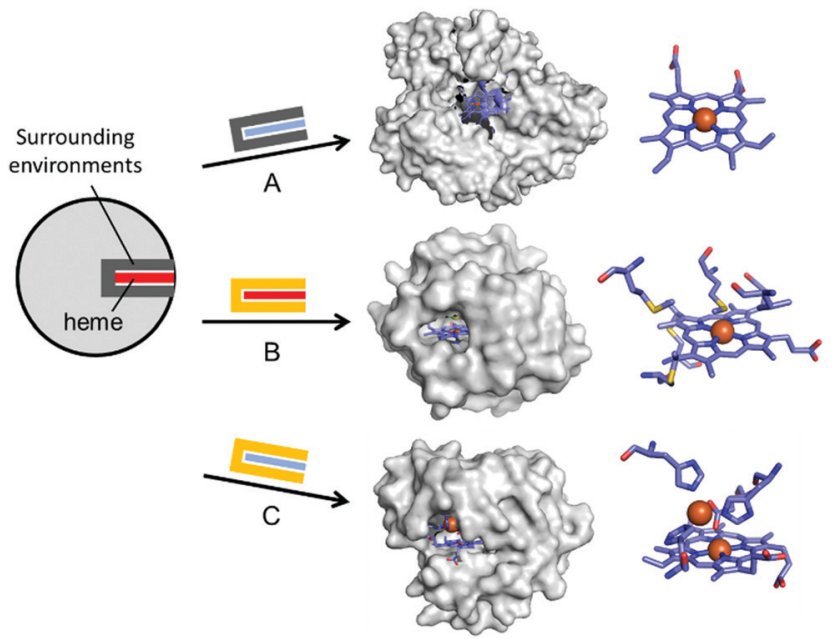

Fig. 4 Representative examples in harnessing the native haem proteins for the design of artificial metalloenzymes. (A) Substitution of haem with synthetic planar complexes in thermophilic cytochrome P450 119 (1/O7). (B) Directed evolution of cytochrome $c$ from Rhodothermus marinus (3CP5). (C) The alterations in both metal-active sites and the surrounding environments of myoglobin-based nitric oxide reductase, $\mathrm{Fe}_{B} \mathrm{Mb}$ (3M39). The native haem and synthetic analogues are depicted with red and blue rectangles, respectively. The native and altered active site pockets encapsulating the heme cofactors are depicted with grey and yellow claws, respectively. The reconstituted cofactors and the first metal-coordination sites are depicted with cyan sticks. PDB codes are given in parentheses.

apo-HydA1. In addition, another enzyme associated with the bio-assembly of [FeFe]-hydrogenase, HydG, was created as an artificial metalloprotein having non-native $\mathrm{Fe}-\mathrm{S}$ clusters. ${ }^{53}$ It natively contains a $4 \mathrm{Fe}-4 \mathrm{~S}$ cluster with the fifth dangling $\mathrm{Fe}$ atom, resulting in a $5 \mathrm{Fe}-4 \mathrm{~S}$ cluster (Fig. 2D). Upon chelation and metal exchange, the fifth metal ion was modified into $\mathrm{Ni}^{2+}$ and $\mathrm{Co}^{2+}$. Alternatively, the fifth metal-ligating $\mathrm{S}$ atom was exchanged into Se. The feasibility of these enzymatic and chemical alterations provide systematic tools to explore the inorganic properties of metalloenzymes and to develop tuneable biocatalysts.

Pre-existing metalloproteins can be harnessed by reshaping the active site pockets for modified substrates and/or reactivities, while the native inorganic elements are kept intact. For example, adenosine deaminase (Scheme 1A) was redesigned into organophosphate hydrolase (Scheme 1B) guided by computer-aided simulation and mutations (Fig. 3D) ${ }^{54}$ Alternatively, both metal elements and the surrounding protein environment can be optimized together, giving rise to even greater alterations in the catalytic reactivities. Glyoxalase II (Fig. 3E), for instance, natively hydrolyses the thiolester bond of $S$-D-lactoylglutathione (Scheme 1C). ${ }^{55}$ The active centre is composed of dinuclear metal-binding sites, where metal ion can be either Fe, Mn, or $\mathrm{Zn}$ ions, exhibiting some degrees of metal promiscuity. In addition, both glyoxalase II and $\beta$-lactamase have $\alpha \beta / \beta \alpha$ four-layer sandwich folds, implicating that they are evolutionarily related and novel $\beta$-lactamase can be created from glyoxalase II. With extensive loop engineering, insertion, deletion, and point mutations, glyoxalase II was transformed
A

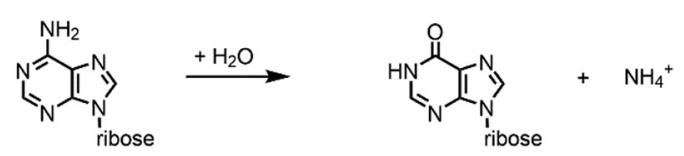

B<smiles>CCOP(=O)(OCC)Oc1ccc2ccc(=O)oc2c1</smiles>

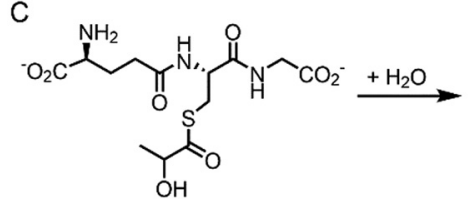<smiles>CCC(O)C(=O)OC(C)C(=O)NCC(=O)NC(=O)CC[C@H](N)C(=O)O</smiles>

D<smiles>CO/N=C(\C(=O)NC1C(=O)N2C(C)=C(COC(C)=O)CSC12)c1csc(N)n1</smiles><smiles>C=C1CSC(NC(=O)C(=O)ON=C(OC)c2csc(N)n2)C(C(=O)O)=N1</smiles>

Scheme 1 Chemical reactions catalysed by the native enzymes and the redesigned metalloenzymes. (A) Adenosine deaminase to (B) phosphatase (C) glyoxalase II to (D) $\beta$-lactamase.

into an artificial $\beta$-lactamase (Scheme 1D), utilizing two $\mathrm{Zn}$ ions in the active site.

Haem proteins have also been iteratively mutated while the native cofactor is kept intact at the active sites. Arnold et al. have created a remarkable series of biocatalysts that exhibit catalytic activities in olefin cyclopropanation, ${ }^{56}$ carbon-silicon bond formation, ${ }^{57}$ chiral organoborane synthesis, ${ }^{58}$ and $\mathrm{sp}^{3}$ $\mathrm{C}-\mathrm{H}$ functionalisation ${ }^{59}$ via carbene transfer (Fig. 4B). In these examples, haem proteins have contributed greatly as scaffolds because the formation of a high-valent iron haem intermediate provides the molecular basis for abiological reactivities in the activation of various small molecules.

Rational modification of haem proteins in both metal centre and surrounding environments has also provided biocatalysts with novel activities. Lu et al. installed three histidine and one glutamate residues in myoglobin, or a $[4 \mathrm{Fe}-4 \mathrm{~S}]$ cluster in cytochrome $c$ peroxidase, resulting in nitric oxide reductase ${ }^{60}$ and sulfite reductase, ${ }^{61}$ respectively (Fig. 4C). The authors also characterised the artificial nitric oxide reductase upon metal substitution to explore distinct inorganic reactivities of $\mathrm{Cu}$ versus Fe. ${ }^{62}$ This structure-based metalloprotein reconstruction allows the synthesis of novel biocatalysts as well as a systematic exploration of the nature and reactivity of metal ions in proteinaceous ligand sets.

\subsection{Native binding affinity}

Selective introduction of inorganic elements becomes the most critical step when a non-metalloprotein is employed as a starting material for the synthesis of artificial metalloenzymes. One successful approach is to harness biological host proteins 
A

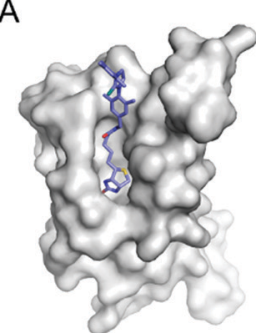

$\mathrm{D}$

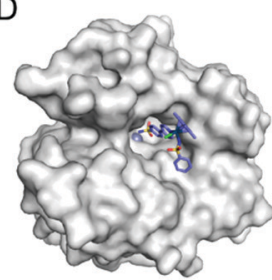

B

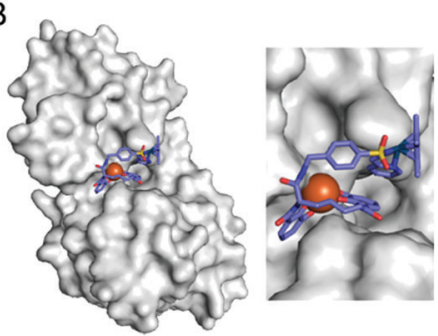

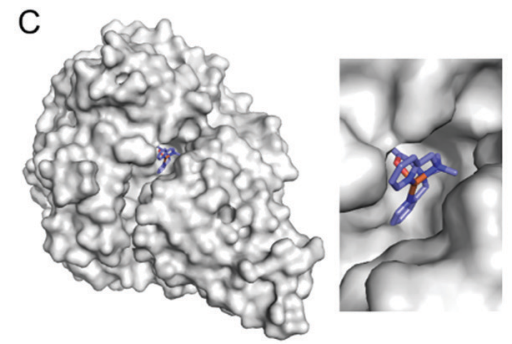

C

E

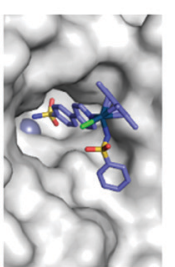

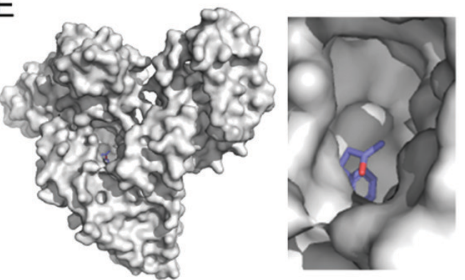

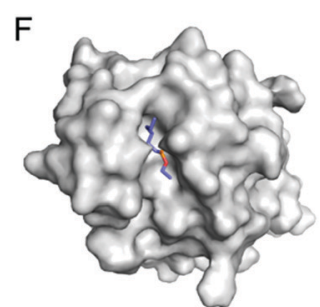

Fig. 5 Representative proteins with the native binding properties. (A) Biotinylated Hoveyda-Grubbs catalyst bound in streptavidin (PDB 5IRA). (B) Periplasmic binding protein CeuE complexed with siderophore-Ir catalyst (5OD5). (C) An Fe complex bound inside nickel binding protein, NikA (4I9D). (D) $\alpha$-Carbonic anhydrase complexed with an inhibitor-Ir catalyst (PDB 3ZP9). (E) A coumarin-derived molecule bound in human serum albumin (1H9Z). (F) The wild-type cutinase-inhibitor complex (1XZL). The active site pockets are enlarged for clarity. The small molecules that bind to the active site of the proteins are depicted with blue sticks. PDB codes are given in parentheses.

with the native binding affinity to guest-like small molecules or ligands (Fig. 5). Ward et al. have employed streptavidin-biotin technology to incorporate inorganic catalysts at the desired position. The tight binding affinity of biotin to streptavidin was retained even upon structural modification of biotin and mutations in streptavidin, yielding a wide range of catalytic activities, such as transfer hydrogenation, ${ }^{63}$ Suzuki-Miyaura cross-coupling, ${ }^{64}$ and metathesis (Fig. 5A). ${ }^{65}$ The catalytic reactivities are derived from inorganic complexes such as Ir $\mathrm{d}^{6}$-piano stool complex (Fig. 6A), monophosphine Pd complex, and Hoveyda-Grubbs catalyst, respectively, which are selectively introduced by the covalent linkage to biotin, whereas the surrounding protein environment contributes to the determination of product distribution and turnover number. Notably, a monomeric version of streptavidin, originally a structure of the versatile protein scaffold for artificial metalloenzymes.

The streptavidin-biotin strategy enabled exploration of novel inorganic reactivity in proteinaceous environments. Borovik et al. recently introduced a mononuclear copper complex, $\mathrm{Cu}($ biot-etdpea), (Fig. 6B) into streptavidin. ${ }^{67}$ The chemical properties of the copper complex were previously investigated in non-aqueous solvents, and they are remarkably altered upon docking on the protein. In particular, hydrogen-bonding with adjacent residues significantly increase the stability of Cu-hydroperoxido species, indicating that proteins are evolvable platforms for metaldependent biocatalysis.

Metal-trafficking proteins have also been exploited along these lines. These proteins exhibit high selectivity and binding affinity for dedicated metal ions or metal complexes, which can be readily utilized to introduce abiological inorganic elements into proteins. Siderophore is an innate chelator and transporter of Fe, exhibiting high selectivity for the ferric state over ferrous ion. As a result, Fe-coordination of azotochelin, a siderophore
A

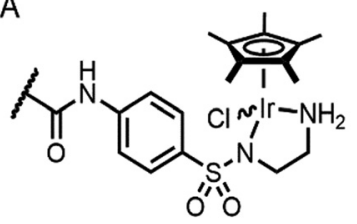

C

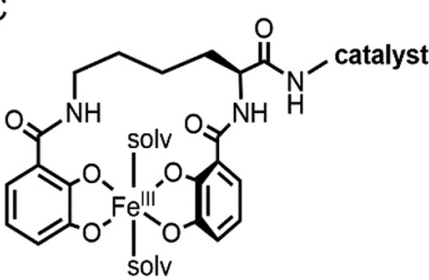

D

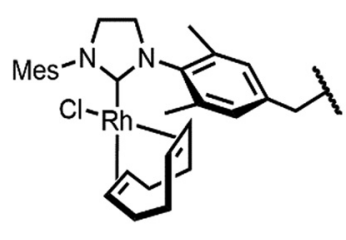<smiles></smiles>

Fig. 6 The structures of representative inorganic complexes described in Sections 2.3 and 2.4. (A) Ir $d^{6}$-piano stool complex for transfer hydrogenation. (B) $\mathrm{Cu}$ (biot-et-dpea) complex, where biotin conjugated moiety is omitted for clarity. (C) Fe azotochelin linked to a catalyst of interest. The conjugated Ir catalyst is omitted for clarity. (D) Rh(NHC) phosphonate. (E) Cu(phen) complex. (F) Co half-sandwich complex. (G) Di-Rh complex. The wavy lines in (A), (B) and (D)-(G) indicate the anchoring point on the proteins.

from Azotobacter vinelandii (Fig. 6C), was linked to a catalyst of interest, such as Ir imine reduction catalyst (Fig. 6A), resulting 
in selective association and dissociation upon oxidation and reduction of Fe, respectively. ${ }^{68}$ In addition, when an Ir catalyst was attached to siderophore, periplasmic binding proteins (PBPs) were transformed into artificial hydrogenase (Fig. 5B). Analogously, a nickel transporter NikA was also utilized as a scaffold to dock a Fe complex such as $\mathrm{Fe}(\mathrm{EDTA})\left(\mathrm{H}_{2} \mathrm{O}\right)^{-}$for catalysis (Fig. 5C). ${ }^{69}$ The NikA-Fe hybrid protein functions as an artificial oxygenase for sulfide oxidation. ${ }^{70}$ Again, similarly to streptavidin, these examples indicate that catalytic activities are derived from metal complexes, when the secondary coordination environments, and consequently, the enzymatic activities, are tuned by protein matrix.

Proteins with inhibitors and strongly-binding ligands have also been utilized as biological hosts. Aryl-sulphonamide, for example, is an inhibitor of carbonic anhydrase (Fig. 5D). ${ }^{71}$ Human serum albumin is a carrier protein, exhibiting well-characterised interactions with coumarin-derivatives (Fig. 5E). ${ }^{72}$ After covalent linking of an IrCp* piano-stool complex or Hoveyda-Grubbs Ru catalyst to an inhibitor and a hydrophobic coumarin ligand, respectively, they became metalloenzymes with asymmetric transfer hydrogenation and ring-closing metathesis activities, respectively.

For serine or cysteine-dependent hydrolases, the catalytically active serine residues can function as nucleophiles to be covalently linked to abiological inorganic elements so that catalytic units can be steered to the native active site pockets. Various organometallic catalysts, such as Hoveyda-Grubbs catalyst, Ir $\mathrm{d}^{6}$-piano stool complex, $\mathrm{Rh}(\mathrm{NHC})$ phosphonate (Fig. 6D), and pincer-type $\mathrm{Pt} \mathrm{d}^{8}$ complex have been attached to hydrolases such as $\alpha$-chymotrypsin, ${ }^{73}$ papain, ${ }^{74}$ lipase, ${ }^{75}$ and cutinase (Fig. 5F), ${ }^{76}$ respectively. Similarly, a serine hydrolase with two catalytic triads was converted into an artificial enzyme for oxidation and Friedel-Crafts alkylation. ${ }^{77}$ One of its catalytic triads was conjugated with a $\mathrm{Cu}$ (bpy) complex, resulting in an artificial metalloenzyme with coupled catalytic activities.

In some cases, binding affinity to introduce external inorganic components to novel environments can be derived from the native protein-protein interaction. Douglas et al. have created artificial metalloenzymes by encapsulating [NiFe]-hydrogenase within the capsid of bacteriophage P22. ${ }^{78}$ The catalytic domain, [NiFe]-hydrogenase, was fused to a protein that exhibits protein-protein interaction with a coat protein. The self-assembled artificial metalloenzyme exhibits enhanced catalytic activity and stability against protease, thermal denaturation, and air exposure, indicating that a combination of two proteins can also give rise to artificial metalloenzymes.

\subsection{Confined and empty spaces in proteins}

Enzyme catalysis, in general, occurs in structurally well-defined active site pockets. In such confined spaces, multiple amino acids encapsulate catalytic units, producing orchestrated multiple steps associated with catalysis, such as substrate-binding, product-release, and protection from adventitious reactions. Substitution of inorganic elements with novel ones in preexisting metalloproteins (described in Section 2.2), therefore, takes advantage of both the binding sites for catalytic units and the well-defined space. Some proteins natively possess these empty spaces, which can be adapted for artificial metalloenzyme catalysis. ${ }^{48}$ Once a protein with a potential cavity for catalysis is selected, the next step is to embed a catalytically active unit in the desired position of the void space. The examples below have employed either cysteine by chemical modification or unnatural amino acids by acyl-tRNA/t-RNA synthase pairs. ${ }^{79,80}$

2.4.1. Cysteine bioconjugation. The distinct chemical properties of cysteine among canonical amino acids as a nucleophile has been applied to selectively anchor metalcoordinating ligands or complexes so that novel inorganic elements can be placed inside proteins. As a result, diverse proteins of various sizes, structures, and functions have been transformed into artificial metalloenzymes, although they exhibit neither pre-existing inorganic elements nor intrinsic affinity for inorganic complexes or small molecules.

Adipocyte lipid binding protein (ALBP), for example, was selected because of its hydrophobic active sites to attach a $\mathrm{Cu}$ (phen) complex (Fig. 6E) for enantioselective ester hydrolysis (Fig. 7A) ${ }^{81}$ Sterol carrier protein type 2 (SCP-2L) also exhibits a cylindrically shaped hydrophobic cavity (Fig. 7B), providing a potential environment for biocatalysis. Bioconjugation of nitrogen-donor ligands to a cysteine inside of the cavity, followed by the addition of $\mathrm{Cu}$ or $\mathrm{Fe}$ ions, leads to the formation of biocatalysts for asymmetric Diels-Alder ${ }^{82}$ and oxidative lignin degradation, ${ }^{83}$ respectively. In addition, two thermally stable proteins described in Section 2.1 (Table 1), $\mathrm{tHisF}^{27}$ (Fig. 7C) and mTFP $^{* 25}$ (Fig. 7D) possess confined spaces within a TIM and a $\beta$-barrel structure, respectively. As a result, the concave regions could be beneficially transformed into the active site of artificial $\mathrm{Cu}$ enzymes by the installation of $2 \mathrm{His} / 1$ carboxylate motif. ${ }^{25,27}$

Chaperonin has also been exploited as a protein nanoreactor owing to its shape: a hexadecameric protein with both open and closed conformations. By covalently linking a Cu-catalyst for atom-transfer radical polymerisation, the concurrent metalloenzyme yielded lower polydispersity indices than the catalyst alone. ${ }^{84}$ Analogously, various cage proteins have been adapted as versatile platforms for catalysis because of their compartmentalized internal space. For example, ferritin is used to encapsulate artificial metalloenzymes composed of streptavidin-biotin complexes. ${ }^{85}$ Significant improvements in the turnover of artificial transfer hydrogenases within ferritin were detected, indicating that proteins with a defined cavity provide a ternary coordination sphere for catalysis. Similarly, a capsid of bacteriophage P22 was also applied as a proteinreactor $^{78}$ as described above.

Barrel-shaped proteins have also been used to generate artificial metalloenzymes because of their large void spaces. Nitrobindin (Fig. 7E), for example, is adapted for polymerisation, hydrogen evolution, and metathesis by anchoring an Rh-catalyst, ${ }^{86}$ a diiron complex, ${ }^{87}$ and a Hoveyda-Grubbs catalysts ${ }^{88}$ inside of the void space, respectively. The hybrid proteins produce either more selective products and/or higher efficiency owing to the unique environments. Similarly, another $\beta$-barrel protein, FhuA (Fig. 7F), was also transformed into artificial metalloenzymes by covalently conjugated to either a Hoveyda-Grubbs catalyst, ${ }^{89} \mathrm{Cu}(\mathrm{NHC})$ 
A

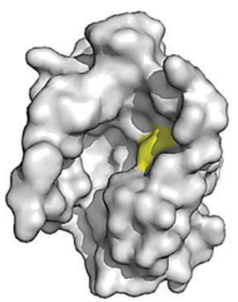

E

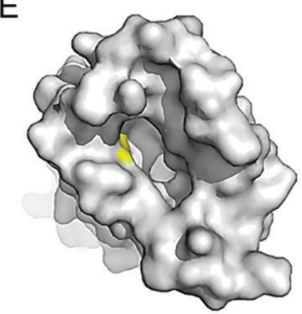

B

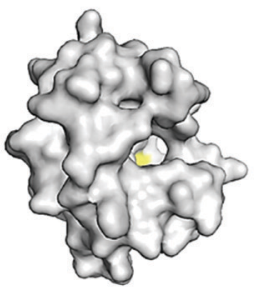

F

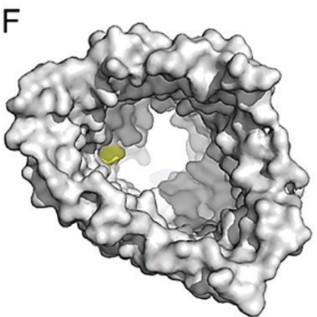

C

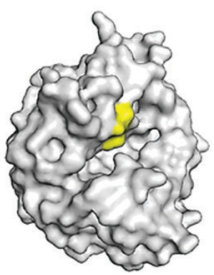

G

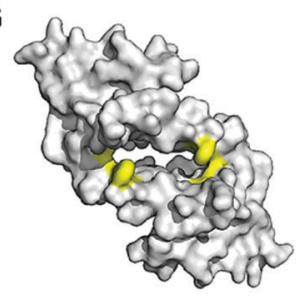

D

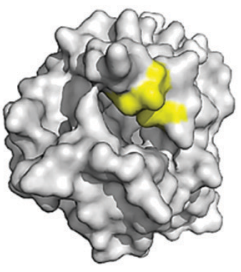

$\mathrm{H}$

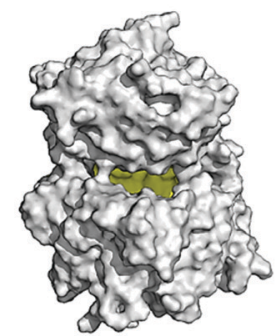

Fig. 7 Representative proteins with the native confined and empty spaces. (A) Adipocyte lipid binding protein (1LIB). (B) Sterol carrier protein 2L (1IKT). (C) Glycerol phosphate synthase $t$ HisF from Thermotoga maritima (1THF). (D) Monomeric cyan fluorescent protein mutant mTFP* from Clavularia sp. (6QSL). (E) Nitrobindin (3EMM). (F) Ferrichrome outer membrane transporter FhuA (1BY3). (G) Multidrug transcriptional regulator LmrR from Lactococcus lactis (3F8B). (H) Prolyl oligopeptidase from Pyrococcus furiosus (5T88). The cavities adapted for novel biocatalysis are coloured in yellow in surface representation. PDB codes are given in parentheses.

complex, ${ }^{90}$ or cobalt half-sandwich complex (Fig. 6F). ${ }^{91}$ As a result, the inherently transmembrane protein that mediates $\mathrm{Fe}$ uptake now exhibits catalytic activities in metathesis, DielsAlder, and cyclotrimerisation of phenylacetylene, respectively. Notably, FhuA is one of the few membrane proteins used for artificial metalloenzyme design, expanding the spectrum of protein scaffolds and reaction conditions for biocatalysis.

2.4.2. Genetic incorporation of metal-chelating residues. Other than cysteine conjugation, unnatural amino acids can be genetically incorporated to directly generate catalytic active sites by metal coordination. Then, inorganic units can be directly positioned within the protein cavity with no need for organic linkers. Roelfes et al. have employed multidrug resistance regulator LmrR as a scaffold for artificial metalloenzyme design (Fig. 7G). ${ }^{92}$ The protein is a homodimer with a large and hydrophobic binding pocket at its dimer interface. Metal ions or inorganic complexes have been introduced by the incorporation of unnatural amino acids such as (2,2'-bipyridin-5yl)alanine, along with the cysteine-mediated conjugation of 2,2'-bipyridine and 1,10-phenanthroline. Consequently, LmrR was successfully transformed into a Cu-binding enzyme that is competent in Friedel-Crafts alkylation of indoles. In addition, the cavity is sufficiently large and promiscuous for haem-binding, facilitating the production of artificial haem enzymes with cyclopropanation activity. ${ }^{93}$ Because metal-binding unnatural amino acids other than bipyridinyl group (Bpy-Ala) have been developed, such as (8-hydroxyquinolin-3-yl)alanine and 2-amino-3-(8-hydroxy-quinolin5 -yl)propanoic acid, ${ }^{80}$ the scope of artificial metalloenzymes using genetic modification can be further expanded in numerous protein scaffolds without being limited to the proteins with pre-existing metal centres or binding affinity for small-molecules.

2.4.3. Introduction of clickable residues. Alternatively, an anchoring point for bioconjugation other than cysteine can be genetically incorporated. Lewis et al. selected a protein platform with a spacious cavity, prolyl oligopeptidase from Pyrococcus furiosus (Fig. $7 \mathrm{H}),{ }^{30,31}$ for biocatalysis. An unnatural amino acid, $p$-azido-L-phenylalanine, was encoded, which is clickable with an alkyne group. ${ }^{94}$ A dirhodium complex (Fig. 6G) was attached inside prolyl oligopeptidase, resulting in selective olefin cyclopropanation. ${ }^{95}$ Notably, the protein originated from a hyperthermophilic organism (Table 1), and thus this stable protein platform could endure several rounds of mutation to improve catalytic activities. ${ }^{96}$

\subsection{Well-defined secondary structures}

Instead of using abiological catalysts, metal-binding sites can be directly created in a de novo approach. By appropriately placing metal-coordinating amino acids, such as glutamate, aspartate, histidine, and cysteine, on non-metalloprotein scaffolds, artificial metalloproteins can be generated. This bottom-up approach presumably resembles how natural metalloproteins might have emerged by utilizing natural metal elements and canonical metal-ligating amino acids. Although this approach can be applied for essentially any protein, a challenge arises owing to our incomplete understanding of protein sequencestructure-function relationship and protein-metal binding interactions. Therefore, de novo metal-binding sites have been synthesized with relatively small and well-characterised proteins, primarily in their secondary structures. Notably, self-assembled protein oligomers comprising of $\alpha$-helixes and $\beta$-sheets have been employed because they form a crevice or pocket-shaped architecture, which is suitable for catalysis, as described in Section 2.4.

2.5.1. $\alpha$-Helical peptides and proteins. The $\alpha$-helical domain is the most extensively investigated secondary structure. A single $\alpha$-helical turn is composed of 3.6 amino acids, which allows us to translate one-dimensional sequence information into three-dimensional protein structures in a relatively predictable manner. Various $\alpha$-helical coiled-coil oligomers have been 
synthesized by placing hydrophobic and charged residues at the interfacial and adjacent sites, respectively. ${ }^{97}$ Because the hydrophobic residues are situated at the core of the oligomers, substitution for metal-binding residues has been an effective strategy to prepare catalytic metallopeptides. ${ }^{98}$

Pecoraro et al. synthesized homo and hetero- $\alpha$-helical trimers as artificial metalloenzymes (Fig. 8A). ${ }^{99}$ The peptides are templated by binding $\mathrm{Hg}^{2+}, \mathrm{Cd}^{2+}$, or $\mathrm{Pb}^{2+}$ where other metal ions such as $\mathrm{Zn}$ and $\mathrm{Cu}$ play catalytic roles, such as in $\mathrm{CO}_{2}$ hydration/ester hydrolysis ${ }^{100,101}$ and nitrite reduction, ${ }^{102,103}$ respectively. Alternatively, $\mathrm{Fe}^{2+}$ can be incorporated into the $\alpha$-helical structure, resulting in a rubredoxin-like protein, facilitating electron transfer. ${ }^{104}$ Similarly, Tanaka et al. also have constructed an artificial dinuclear Cu-binding site by placing two histidine and two cysteine residues into a four- $\alpha$-helical coiled-coil, yielding two copper atoms bridged with two cysteines (Fig. 8B). ${ }^{105}$ Spectroscopic characterisation suggests that the artificial metalloenzyme is a structural and functional mimic of cytochrome $c$ oxidase.

In addition, $\alpha$-helical peptides have been versatile platforms to anchor a dirhodium centre. Ball et al. created artificial metallopeptides with catalytic activity in enantioselective carbenoid insertion into $\mathrm{Si}-\mathrm{H}$ bonds ${ }^{106}$ and asymmetric cyclopropanation. ${ }^{107}$ Kuhlman et al. have also designed metal-binding histidine residues on $\alpha$-helical peptides, resulting in dimeric metalloproteins with crevice-like architectures (Fig. 8C). ${ }^{108}$ These peptides were further engineered and evolved into a globular metallo-esterase with high enantiospecificity and catalytic efficiency (Fig. 8D). ${ }^{109}$

Four $\alpha$-helical bundle proteins have also been extensively employed for the design of artificial metalloenzymes. Dutton et al. have created maquettes that bind haem for $\mathrm{O}_{2}$ transport ${ }^{110}$ or exhibit oxidoreductase activity with haem, flavins, Fe-S clusters, $\mathrm{Zn}$ porphyrins, and $\mathrm{Zn}$ chlorines. ${ }^{111}$ The proteins were further engineered into artificial oxidases that react with a diverse array of substrates using hydrogen peroxide as an oxidant. ${ }^{112}$
Tezcan et al. employed a four $\alpha$-helical bundle protein, cytochrome $c b_{562}$, as a monomer to generate self-assembled tetramers as a $16 \alpha$-helical bundle protein. ${ }^{113,114}$ Rational and in silico redesign produced a tetrameric metalloprotein (Fig. 8E), creating protein-protein interfaces for the sites for metal-dependent hydrolysis even inside E. coli cells. ${ }^{115}$ The $\alpha$-helical protein scaffold is so versatile that various proteins that bind a wide array of first-row transition metal ions can be effectively generated, ${ }^{116}$ and the diversion of evolutionary paths differed by local flexibility can be also explored. ${ }^{117}$

DeGrado and Lombardi et al. have designed a de novo Due Ferri protein (Fig. 8F), ${ }^{118,119}$ where the four $\alpha$-helix bundles provide a dinuclear Fe-coordinating site for selective $N$-hydroxylation of arylamines ${ }^{118}$ and artificial phenol oxidase activity. ${ }^{119}$ Alternatively, the four $\alpha$-helix bundle generated the sites for tetra-nuclear clusters ${ }^{120}$ and for highly electrondeficient non-natural zinc porphyrin, the latter of which was highly stable even at $100{ }^{\circ} \mathrm{C} .{ }^{121}$

Other than soluble $\alpha$-helical proteins, DeGrado et al. reported the de novo design of a functional four $\alpha$-helix transmembrane protein. ${ }^{122}$ Despite great challenges in the design of transmembrane proteins, ${ }^{123,124}$ the group has designed two stable asymmetric states with a dynamic interface to transport selective metal ions, such as $\mathrm{Zn}^{2+}$ and $\mathrm{Co}^{2+}$ but not $\mathrm{Ca}^{2+}$, across membranes. Although the protein exhibits no catalytic activity, this work suggests that the scope of $\alpha$-helical scaffolds can be extended to membrane proteins. In addition, the sequence, structure, and function of $\alpha$-helical proteins can be further expanded as exemplified with a combinatory library of $\alpha$-helical proteins and their emergence of peroxidase activity. ${ }^{125}$ Therefore, $\alpha$-helical proteins are likely to contribute more versatile scaffolds for de novo artificial metalloenzymes in the future.

2.5.2. $\beta$-Sheet peptides and proteins. In contrast to $\alpha$-helical proteins, few $\beta$-sheet proteins have been adapted for the de novo design of metal-binding sites. However, they could
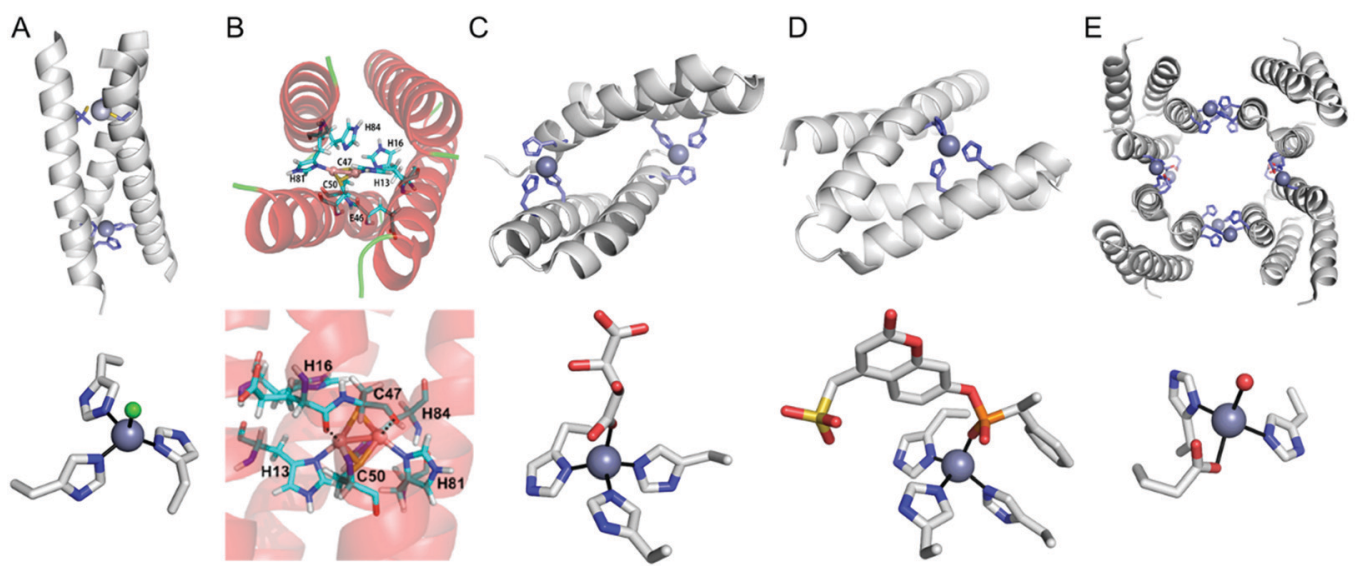

$\mathrm{F}$
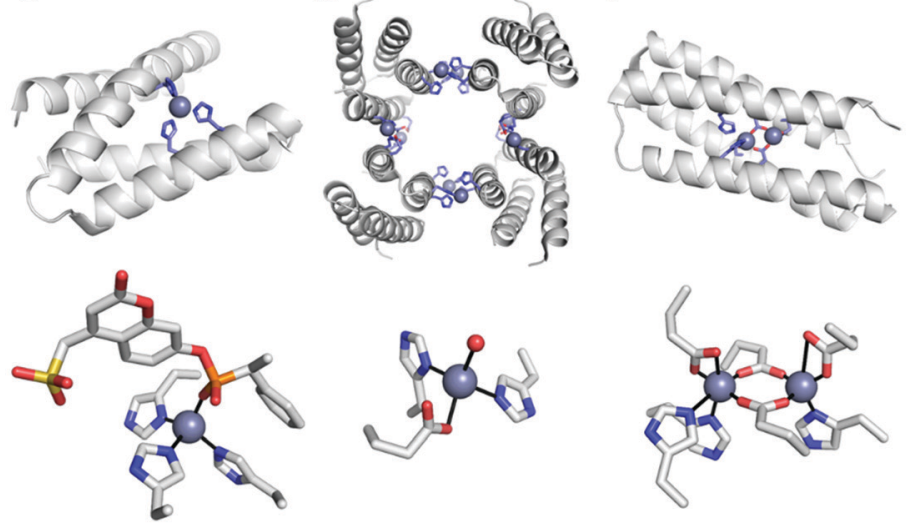

Fig. 8 Representative structures of de novo metallo- $\alpha$-helical peptides and proteins (A) Zn-dependent metallo-esterase (3PBJ). (B) A structural model of the dicopper-binding protein. Reprinted with permission from ref. 105. Copyright (2012) American Chemical Society. (C) Zn-Dependent hydrolase MID1-Zn (3V1C). (D) Zn-Dependent hydrolase MID1sc10 (5OD1). (E) Zn-Dependent $\beta$-lactamase (4U9E). (F) Diiron artificial metalloenzyme 3His-G2DFsC (2LFD). PDB codes are given in parentheses. Metal atoms and metal-ligating residues are shown with navy spheres and sticks, respectively. In (C) and (D), co-crystallized metal-binding molecules are also shown with sticks. The metal-bound chloride and water-derived molecule are coloured in green and red, respectively. 
be unique platforms for metal-dependent biocatalysts. Previously, artificial rubredoxin was created using a de novo synthesized $\beta$-sheet protein, ${ }^{126}$ mimicking the structure of the native rubredoxin as a small and mostly $\beta$-sheet protein. ${ }^{127}$ The protein provided stable coordination sites for $\mathrm{Fe}$ at both oxidation states, $\mathrm{Fe}^{2+}$ and $\mathrm{Fe}^{3+}$, resulting in a reversible oxidoreductase. De novo $\beta$-sheet peptides have also been synthesized to ligate haem with bis-His coordination. ${ }^{128}$ The metallopeptide exhibited peroxidase activity and mediated electron transfer to cytochrome $c$ protein, resulting in artificial oxidoreductase. The $\beta$-barrel proteins, primarily composed of $\beta$-sheets, are also versatile scaffolds for artificial metalloenzymes. In particular, as described above in Section 2.4.1, $\beta$-barrel proteins, such as nitrobindin and FhuA, have internal void space, which can be applied for the insertion of inorganic elements and concurrent catalysis.

One of the challenges associated with $\beta$-sheet proteins is their propensity to aggregate and form fibril structures. Although such structural features can give rise to more heterogeneous and poorly defined states for catalysis, they can be catalytically active with exogenous substrates. For example, a seven-amino acid-long $\beta$-sheet peptide was converted into an artificial enzyme upon the addition of $\mathrm{Zn}$ and $\mathrm{Cu}$, hydrolysing $p$-nitrophenyl acetate ${ }^{129}$ and paraoxon, ${ }^{130}$ respectively. The catalytic activity was measured in amyloid-like fibril structures, providing kinetic advantages in high local concentrations, as often shown in heterogeneous catalysts. Notably, analogous amyloid-like structures and hydrolase activity were observed with a Zn-coordinated phenylalanine amino acid, with no assistance of any peptide or protein. ${ }^{131}$ These data indicate that a heterogeneous biomaterial may generate catalytic environments, similar to the function of a protein matrix.

In addition, intermolecular space upon self-assembly of $\beta$-sheet proteins can be generated for catalysis, similar to supramolecular structures of $\alpha$-helical proteins. A computationally redesigned $\beta$-propeller protein (Pizza6) demonstrated that a $\beta$-structural protein can produce 19-atom nanocrystals within the protein-protein interface. ${ }^{132}$ Although this work was carried out for biomineralisation rather than for catalysis, the successful positioning of metal centres in a concave pocket suggests that artificial metalloenzymes can be created in $\beta$-structural proteins.

\subsection{Native cellular location of proteins}

The accessibility of synthetic complexes and non-native substrates becomes essential for the in vivo activity of artificial metalloenzymes. Then, unnatural components should bypass the cell membrane to bind the target proteins. In addition, potential interference with other proteins, metabolites such as glutathione, and salts must also be overcome. To this end, reaction conditions can be implemented to resolve the issue. ${ }^{133,134}$ A native leader sequence has been also applied to several non-periplasmic proteins for translocation, ${ }^{65,115}$ including streptavidin and cytochrome $b_{562}$, described in Sections 2.3 and 2.5.1, respectively. As a result, they were placed in the periplasm, where abiological catalysts, substrates, and metal ions at nonphysiological concentrations can be more readily reached than in the cytosol.

In addition, a protein of interest can be fused to a membrane protein such as a truncated lipoprotein and an outer membrane protein, resulting in the positioning of the artificial metalloenzyme on the cell surface (Fig. 9A). ${ }^{135}$ Alternatively, membrane protein by itself can be directly converted to artificial metalloenzymes. An A2A adenosine receptor is natively embedded in the cytoplasmic membranes of human embryonic kidney cells (Fig. 9B), ${ }^{136}$ displaying strong association with its antagonists. When a $\mathrm{Cu}$ catalyst covalently anchored to the antagonist was introduced, the A2A adenosine receptor became an artificial Diels-Alderase that is reactive with abiological substrates such as cyclopentadiene and 2-azachalcone.

\section{Additional considerations in the selection of protein platforms}

\subsection{Native geometric parameters}

An alternative promising approach for the design of artificial metalloenzymes would be to search for non-metalloproteins that possess a pre-arranged set of residues for metal coordination. Ward et al. have carried out data mining on facial triad motifs, which is one of the most extensively investigated mononuclear metal-binding sites, ${ }^{137,138}$ comprised of two histidine
A

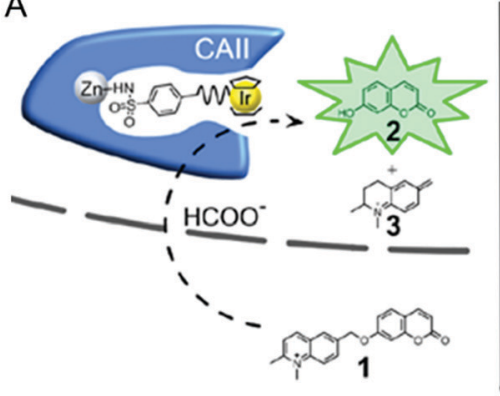

periplasm

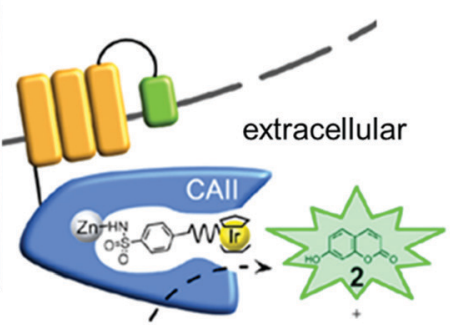

B

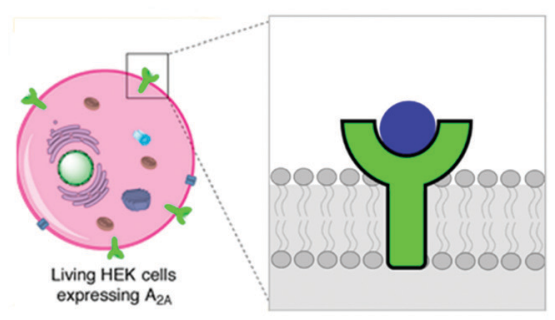

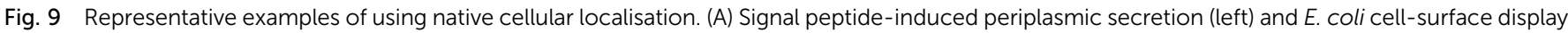

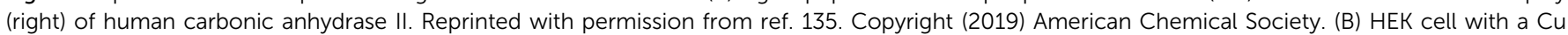
complex bound A2A receptor. Reprinted with permission from ref. 136. Copyright (2018) American Chemical Society. 
and one-carboxylate residues in facial position of octahedral geometry. ${ }^{139}$ From the motif search on the Protein Data Bank (PDB), they discovered 121 viable triads, implicating that they can be amendable for metal coordination and, possibly, novel metal-dependent catalysis.

Lai and He et al. have also applied computational screening to identify proteins with a set of residues that potentially bind uranyl $\left(\mathrm{UO}_{2}{ }^{2+}\right)$ upon mutation. ${ }^{140}$ Because uranyl ion prefers pentagonal or hexagonal bipyramidal geometry upon coordination to five to six ligating oxygen atoms at the equatorial positions, protein structures were examined to find the sets of amino acids that can be mutated to two or three carboxylate in a plane to accommodate uranyl-binding. The protein was further engineered to a novel protein with femtomolar affinity for uranyl ions and greater than $10^{4}$-fold selectivity over other metal ions.

In addition, protein symmetry can simplify the design of de novo metalloenzymes. When a metal-binding active site is created at the protein-protein interface, symmetry operation multiplies the metal-ligating residues, reducing the number of residues to design. Kerfeld et al., for example, engineered bacterial microcompartment shell protein (BMC) to create a $4 \mathrm{Fe}-4 \mathrm{~S}$ cluster site that mediates multi-electron transfer. ${ }^{141}$ Site-directed mutagenesis of a residue at the site of three-fold symmetry leads to the formation of three equivalent cysteine residues for Fe-binding. The $[4 \mathrm{Fe}-4 \mathrm{~S}]$ clusters mimic the coordination environment of aconitase and radical $S$-adenosylmethionine (SAM) enzyme, whereas its redox properties are analogous to those of bacterial ferredoxins.

As protein structural databases expand and search algorithms become more accurate and finely detailed, geometric factors for metal coordination will become more important in the de novo design of metalloenzymes. Presumably, the orchestration with adjacent residues and/or dynamic motion during catalysis can be also simulated for artificial metalloenzymes, if the search target is beyond the first coordination sphere.

\subsection{Native functions}

If the native function of protein scaffolds, such as substrate binding affinity, electron/proton transfer pathway, and hydrogenbonding network, can be adapted for the aimed novel catalytic activity of artificial metalloenzymes, the protein would be a privileged starting point. Although this sounds obvious, such properties related in enzyme catalysis have been rarely considered in the designing process. Presumably, this is because most protein platforms have been limited by the methods to introduce inorganic elements into the non-metalloproteins. De novo design of metal-binding sites, however, relieves the restrictions associated with pre-existing inorganic elements or the binding affinity to small molecules. One related example is the transformation of ferredoxin into artificial hydrogenase by anchoring $\left[\mathrm{Ru}(\mathrm{bpy})_{3}\right]^{2+}$ and cobaloxime catalyst. ${ }^{142}$ The authors utilized the native electron transfer protein as a scaffold to mediate electron relay between the installed abiological elements. The protein scaffold presumably contributed to the biocatalyst by facilitating electron transfer in a thermodynamically and kinetically favourable manner.

\subsection{Protein dynamics and evolvability}

Knowing how elegant and sophisticated natural enzymes are operative when achieving dedicated chemical transformation, steps other than the introduction of catalytically active inorganic elements may be necessary for the design of novel and efficient biocatalysts. One of the factors that are rarely considered is protein dynamics. A series of conformational changes upon substrate binding and consumption of co-substrates are well documented in numerous examples, ${ }^{143,144}$ implying that multiconformations may be beneficial in the design of artificial metalloenzymes. Protein evolvability would be another factor to consider because it is a measure of adaptability for novel structure and functions. ${ }^{145}$ Although it is difficult to predict and quantitatively determine the degrees of evolvability, recent sequence analysis and prediction indicate that ancestor genes can be reconstructed and be efficiently diverged to exhibit novel catalytic activities, ${ }^{146,147}$ implying that evolvable protein scaffolds can be considered for the design of artificial metalloenzymes.

\subsection{Membrane proteins}

Membrane proteins account for approximately a third of genomes and proteomes in many organisms ranging from Gram-negative bacteria to Homo sapiens. ${ }^{148,149}$ In addition to their natural abundance and diversity, numerous membrane proteins are responsible for essential chemical transformations and biochemical processes, including trafficking, signalling, and transport. As mentioned in Section 2.6, the cellular localisation of enzymes becomes important in the accessibility of abiological components for catalysis. Therefore, membrane proteins are attractive platforms for the generation of artificial metalloenzymes. Despite their natural abundance, diversity, and potential, very few membrane proteins have been utilized for enzyme design.

It is presumably ascribed to the difficulties in the preparation and handling of membrane proteins. Heterologous expression of membrane proteins often leads to the formation of inclusion bodies, which requires extraction and purification of aggregated proteins using detergents. The additional steps are non-trivial and laborious, as reflected in the RCSB database, where only $1-3 \%$ datasets account for the structures of membrane proteins. Indeed, among the numerous examples discussed in the present review, only three are membrane proteins, a $\beta$-barrel protein, FhuA, ${ }^{89-91}$ a de novo designed $\alpha$-helical coiled-coil, ${ }^{122}$ and an A2A adenosine receptor protein. ${ }^{136}$ Membrane proteins, however, would be prospective protein scaffolds because more atomic structural information has become available owing to tremendous advances and applications in the preparation of membrane proteins and determination of three-dimensional structures by cryo-electron microscopy. The availability of structural information, in particular, would link the sequence and molecular function of membrane proteins, allowing us to inspect more diverse scaffolds for artificial metalloenzymes. In addition, as we further explore the folding landscape and sequence-structure-function relationship of membrane proteins, it is expected that we will be able to utilize 
a diverse range of these proteins for the design of artificial metalloenzymes.

\section{Conclusions}

In the present review, we have highlighted recent studies on the design of artificial metalloenzymes. By extracting and categorising the essential and beneficial properties of proteins that are adapted as the scaffolds for metal-mediated biocatalysis, we compiled six underlying desirable factors that should be considered when choosing new ones. Because immense protein sequence and structural databases are being updated daily, including tailor-made proteins, ${ }^{150}$ the scope of targeting reactions, inorganic elements, and catalytic conditions is expected to increase dramatically in the near future. In addition, computer-aided metalloenzyme design, including protein-metal interaction, protein-substrate docking, energy calculation of metal-derived intermediates, would provide accurate and in-depth insights on how protein and metal cooperate in enzyme catalysis. ${ }^{151,152}$ The synergistic combination of chemo-synthetic and biochemical elements for the design of artificial metalloenzymes will expand the chemical repertoire of metal-mediated enzyme catalysis, aiming for high catalytic efficiency, selectivity, tunability, and stability. Simultaneously, it will provide a framework for the exploration of protein sequence-structure-function relationship, enzyme evolution, and inorganic reactivity in proteinaceous environments.

\section{Conflicts of interest}

There are no conflicts to declare.

\section{Acknowledgements}

This work was supported by the Creative-pioneering researchers programme from Seoul National University (SNU) and National Research Foundation from Korea government (NRF2019R1C1C1003863).

\section{References}

1 S. J. Lippard and J. M. Berg, Principles of Bioinorganic Chemistry, University Science Books, 1994.

2 H. B. Gray, E. I. Stiefel, J. S. Valentine and I. Bertini, Biological Inorganic Chemistry: Structure and Reactivity, University Science Book, 2006.

3 U. T. Bornscheuer, G. W. Huisman, R. J. Kazlauskas, S. Lutz, J. C. Moore and K. Robins, Nature, 2012, 485, 185-194.

4 V. Nanda and R. L. Koder, Nat. Chem., 2010, 2, 15-24.

5 F. Schwizer, Y. Okamoto, T. Heinisch, Y. Gu, M. M. Pellizzoni, V. Lebrun, R. Reuter, V. Köhler, J. C. Lewis and T. R. Ward, Chem. Rev., 2018, 118, 142-231.

6 F. Yu, V. M. Cangelosi, M. L. Zastrow, M. Tegoni, J. S. Plegaria, A. G. Tebo, C. S. Mocny, L. Ruckthong, H. Qayyum and V. L. Pecoraro, Chem. Rev., 2014, 114, 3495-3578.

7 F. Nastri, M. Chino, O. Maglio, A. Bhagi-Damodaran, Y. Lu and A. Lombardi, Chem. Soc. Rev., 2016, 45, 5020-5054.

8 J. C. Lewis, ACS Catal., 2013, 3, 2954-2975.

9 T. K. Hyster and T. R. Ward, Angew. Chem., Int. Ed., 2016, 55, 7344-7357.
10 H. J. Davis and T. R. Ward, ACS Cent. Sci., 2019, 5, 1120-1136.

11 Y.-W. Lin, Coord. Chem. Rev., 2017, 336, 1-27.

12 G. D. Haki and S. K. Rakshit, Bioresour. Technol., 2003, 89, 17-34.

13 J. D. Bloom, S. T. Labthavikul, C. R. Otey and F. H. Arnold, Proc. Natl. Acad. Sci. U. S. A., 2006, 103, 5869-5874.

14 N. Tokuriki, F. Stricher, L. Serrano and D. S. Tawfik, PLoS Comput. Biol., 2008, 4, e1000002.

15 P. Shih, D. R. Holland and J. F. Kirsch, Protein Sci., 1995, 4, 2050-2062.

16 S. Venkataramani, J. Truntzer and D. R. Coleman, J. Pharm. BioAllied Sci., 2013, 5, 148-153.

17 V. A. Borzova, K. A. Markossian, N. A. Chebotareva, S. Y. Kleymenov, N. B. Poliansky, K. O. Muranov, V. A. Stein-Margolina, V. V. Shubin, D. I. Markov and B. I. Kurganov, PLoS One, 2016, 11, e0153495.

18 R. Li, Z. Wu, Y. Wangb, L. Ding and Y. Wang, Biotechnol. Rep., 2016, 9, 46-52.

19 S. A. Isarov and J. K. Pokorski, ACS Macro Lett., 2015, 4, 969-973.

20 M. Leurs, B. Dorn, S. Wilhelm, M. Manisegaran and J. C. Tiller, Chem. - Eur. J., 2018, 24, 10859-10867.

21 M. Filice, O. Romero, A. Aires, J. M. Guisan, A. Rumbero and J. M. Palomo, Adv. Synth. Catal., 2015, 357, 2687-2696.

22 X. Li, Y. Cao, K. Luo, Y. Sun, J. Xiong, L. Wang, Z. Liu, J. Li, J. Ma, J. Ge, H. Xiao and R. N. Zare, Nat. Catal., 2019, 2, 718-725.

23 Q. A. T. Le, J. C. Joo, Y. J. Yoo and Y. H. Kim, Biotechnol. Bioeng., 2012, 109, 867-876.

24 J. Zdarta, M. Wysokowski, M. Norman, A. Kołodziejczak-Radzimska, D. Moszyński, H. Maciejewski, H. Ehrlich and T. Jesionowski, Int. J. Mol. Sci., 2016, 17, 1581.

25 J. Fischer, D. Renn, F. Quitterer, A. Radhakrishnan, M. Liu, A. Makki, S. Ghorpade, M. Rueping, S. T. Arold, M. Groll and J. Eppinger, ACS Catal., 2019, 9, 11371-11380.

26 L. Carstensen, G. Zoldák, F.-X. Schmid and R. Sterner, Biochemistry, 2012, 51, 3420-3432.

27 J. Podtetenieff, A. Taglieber, E. Bill, E. J. Reijerse and M. T. Reetz, Angew. Chem. Int. Ed., 2010, 49, 5151-5155.

28 J. P. Casey Jr, R. J. Barbero, N. Heldman and A. M. Belcher, J. Am. Chem. Soc., 2014, 136, 16508-16514.

29 N. Fujieda, T. Nakano, Y. Taniguchi, H. Ichihashi, H. Sugimoto, Y. Morimoto, Y. Nishikawa, G. Kurisu and S. Itoh, J. Am. Chem. Soc., 2017, 139, 5149-5155.

30 V. J. Harwood, J. D. Denson, K. A. Robinson-Bidle and H. J. Schreier, J. Bacteriol., 1997, 179, 3613-3618.

31 M. N. Harris, J. D. Madura, L. J. Ming and V. J. Harwood, J. Biol. Chem., 2001, 276, 19310-19317.

32 R. Kazlauskas, Chem. Soc. Rev., 2018, 47, 9026-9045.

33 C. Savojardo, P. Fariselli, P. L. Martelli and R. Casadio, Bioinformatics, 2016, 32, 2542-2544.

34 T. Ku, P. Lu, C. Chan, T. Wang, S. Lai, P. Lyu and N. Hsiao, Comput. Biol. Chem., 2009, 33, 445-450.

35 F. Pucci, R. Bourgeas and M. Rooman, Sci. Rep., 2016, 6, 23257.

36 C. E. Valdez, Q. A. Smith, M. R. Nechay and A. N. Alexandrova, Acc. Chem. Res., 2014, 47, 3110-3117.

37 H. Eom and W. J. Song, J. Biol. Inorg. Chem., 2019, 24, 517-531.

38 A. Pordea, Curr. Opin. Chem. Biol., 2015, 25, 124-132.

39 P. J. O'Brien and D. Herschlag, Chem. Biol., 1999, 6, R91-R105.

40 I. Nobeli, A. D. Favia and J. M. Thornton, Nat. Biotechnol., 2009, 27, 157-167.

41 O. Khersonsky and D. S. Tawfik, Annu. Rev. Biochem., 2010, 79, 471-505.

42 V. Putignano, A. Rosato, L. Banci and C. Andreini, Nucleic Acids Res., 2018, 46, D459-d464.

43 J. Liu, K. K. Meier, S. Tian, J. L. Zhang, H. Guo, C. E. Schulz, H. Robinson, M. J. Nilges, E. Münck and Y. Lu, J. Am. Chem. Soc., 2014, 136, 12337-12344.

44 J. W. Slater and H. S. Shafaat, J. Phys. Chem. Lett., 2015, 6, 3731-3736.

45 S. Abe, K. Hirata, T. Ueno, K. Morino, N. Shimizu, M. Yamamoto, M. Takata, E. Yashima and Y. Watanabe, J. Am. Chem. Soc., 2009, 131, 6958-6960.

46 L. Fruk, C.-H. Kuo, E. Torres and C. M. Niemeyer, Angew. Chem. Int. Ed., 2009, 48, 1550-1574.

47 T. Hayashi, Y. Hitomi, T. Takimura, A. Tomokuni, T. Mizutani, Y. Hisaeda and H. Ogoshi, Coord. Chem. Rev., 1999, 190-192, 961-974. 
48 T. Ueno, S. Abe, N. Yokoi and Y. Watanabe, Coord. Chem. Rev., 2007, 251, 2717-2731.

49 K. Oohora, H. Meichin, Y. Kihira, H. Sugimoto, Y. Shiro and T. Hayashi, J. Am. Chem. Soc., 2017, 139, 18460-18463.

50 M. W. Wolf, D. A. Vargas and N. Lehnert, Inorg. Chem., 2017, 56, 5623-5635.

51 H. M. Key, P. Dydio, D. S. Clark and J. F. Hartwig, Nature, 2016, 534, 534-537.

52 G. Berggren, A. Adamska, C. Lambertz, T. R. Simmons, J. Esselborn, M. Atta, S. Gambarelli, J. M. Mouesca, E. Reijerse, W. Lubitz, T. Happe, V. Artero and M. Fontecave, Nature, 2013, 499, 66-69.

53 G. Rao, K. B. Alwan, N. J. Blackburn and R. D. Britt, Inorg. Chem., 2019, 58, 12601-12608.

54 S. D. Khare, Y. Kipnis, P. Greisen Jr., R. Takeuchi, Y. Ashani, M. Goldsmith, Y. Song, J. L. Gallaher, I. Silman, H. Leader, J. L. Sussman, B. L. Stoddard, D. S. Tawfik and D. Baker, Nat. Chem. Biol., 2012, 8, 294-300.

55 H.-S. Park, S.-H. Nam, J. K. Lee, C. N. Yoon, B. Mannervik, S. J. Benkovic and H.-S. Kim, Science, 2006, 311, 535-538.

56 P. S. Coelho, E. M. Brustad, A. Kannan and F. H. Arnold, Science, 2013, 339, 307-310.

57 S. B. Kan, R. D. Lewis, K. Chen and F. H. Arnold, Science, 2016, 354, 1048-1051.

58 S. B. J. Kan, X. Huang, Y. Gumulya, K. Chen and F. H. Arnold, Nature, 2017, 552, 132-136.

59 R. K. Zhang, K. Chen, X. Huang, L. Wohlschlager, H. Renata and F. H. Arnold, Nature, 2019, 565, 67-72.

60 N. Yeung, Y.-W. Lin, Y.-G. Gao, X. Zhao, B. S. Russell, L. Lei, K. D. Miner, H. Robinson and Y. Lu, Nature, 2009, 462, 1079-1082.

61 E. N. Mirts, I. D. Petrik, P. Hosseinzadeh, M. J. Nilges and Y. Lu, Science, 2018, 361, 1098-1101.

62 A. Bhagi-Damodaran, M. A. Michael, Q. Zhu, J. Reed, B. A. Sandoval, E. N. Mirts, S. Chakraborty, P. Moënne-Loccoz, Y. Zhang and Y. Lu, Nat. Chem., 2017, 9, 257-263.

63 V. Köhler, Y. M. Wilson, M. Dürrenberger, D. Ghislieri, E. Churakova, T. Quinto, L. Knörr, D. Häussinger, F. Hollmann, N. J. Turner and T. R. Ward, Nat. Chem., 2013, 5, 93-99.

64 A. Chatterjee, H. Mallin, J. Klehr, J. Vallapurackal, A. D. Finke, L. Vera, M. Marsh and T. R. Ward, Chem. Sci., 2016, 7, 673-677.

65 M. Jeschek, R. Reuter, T. Heinisch, C. Trindler, J. Klehr, S. Panke and T. R. Ward, Nature, 2016, 537, 661-665.

66 S. Wu, Y. Zhou, J. G. Rebelein, M. Kuhn, H. Mallin, J. Zhao, N. V. Igareta and T. R. Ward, J. Am. Chem. Soc., 2019, 141, 15869-15878.

67 S. I. Mann, T. Heinisch, T. R. Ward and A. S. Borovik, J. Am. Chem. Soc., 2017, 139, 17289-17292.

68 D. J. Raines, J. E. Clarke, E. V. Blagova, E. J. Dodson, K. S. Wilson and A.-K. Duhme-Klair, Nat. Catal., 2018, 1, 680-688.

69 M. V. Cherrier, L. Martin, C. Cavazza, L. Jacquamet, D. Lemaire, J. Gaillard and J. C. Fontecilla-Camps, J. Am. Chem. Soc., 2005, 127, 10075-10082.

70 C. Esmieu, M. V. Cherrier, P. Amara, E. Girgenti, C. MarchiDelapierre, F. Oddon, M. Iannello, A. Jorge-Robin, C. Cavazza and S. Ménage, Angew. Chem. Int. Ed., 2013, 52, 3922-3925.

71 F. W. Monnard, E. S. Nogueira, T. Heinisch, T. Schirmer and T. R. Ward, Chem. Sci., 2013, 4, 3269-3274.

72 S. Eda, I. Nasibullin, K. Vong, N. Kudo, M. Yoshida, A. Kurbangalieva and K. Tanaka, Nat. Catal., 2019, 2, 780-792.

73 T. Matsuo, C. Imai, T. Yoshida, T. Saito, T. Hayashi and S. Hirota, Chem. Commun., 2012, 48, 1662-1664.

74 P. Haquette, M. Salmain, K. Svedlung, A. Martel, B. Rudolf, J. Zakrzewski, S. Cordier, T. Roisnel, C. Fosse and G. Jaouen, ChemBioChem, 2007, 8, 224-231.

75 M. Basauri-Molina, C. F. Riemersma, M. A. Würdemann, H. Kleijn and R. J. M. Klein Gebbink, Chem. Commun., 2015, 51, 6792-6795.

76 C. A. Kruithof, M. A. Casado, G. Guillena, M. R. Egmond, A. van der Kerk-van Hoof, A. J. Heck, R. J. Klein Gebbink and G. van Koten, Chem. - Eur. J., 2005, 11, 6869-6877.

77 S. Alonso, G. Santiago, I. Cea-Rama, L. Fernandez-Lopez, C. Coscolín, J. Modregger, A. K. Ressmann, M. Martínez-Martínez, H. Marrero, R. Bargiela, M. Pita, J. L. Gonzalez-Alfonso, M. L. Briand, D. Rojo, C. Barbas, F. J. Plou, P. N. Golyshin, P. Shahgaldian, J. Sanz-Aparicio, V. Guallar and M. Ferrer, Nat. Catal., 2020, 3, 319-328.
78 P. C. Jordan, D. P. Patterson, K. N. Saboda, E. J. Edwards, H. M. Miettinen, G. Basu, M. C. Thielges and T. Douglas, Nat. Chem., 2016, 8, 179-185.

79 C. C. Liu and P. G. Schultz, Annu. Rev. Biochem., 2010, 79, 413-444.

80 C. Hu, S. I. Chan, E. B. Sawyer, Y. Yu and J. Wang, Chem. Soc. Rev., 2014, 43, 6498-6510.

81 R. R. Davies and M. D. Distefano, J. Am. Chem. Soc., 1997, 119, 11643-11652.

82 P. J. Deuss, G. Popa, A. M. Z. Slawin, W. Laan and P. C. J. Kamer, ChemCatChem, 2013, 5, 1184-1191.

83 M. V. Doble, A. G. Jarvis, A. C. C. Ward, J. D. Colburn, J. P. Götze, M. Bühl and P. C. J. Kamer, ACS Sustainable Chem. Eng., 2018, 6, 15100-15107.

84 K. Renggli, M. G. Nussbaumer, R. Urbani, T. Pfohl and N. Bruns, Angew. Chem., Int. Ed., 2014, 53, 1443-1447.

85 M. Hestericová, T. Heinisch, M. Lenz and T. R. Ward, Dalton Trans., 2018, 47, 10837-10841.

86 A. Onoda, K. Fukumoto, M. Arlt, M. Bocola, U. Schwaneberg and T. Hayashi, Chem. Commun., 2012, 48, 9756-9758.

87 A. Onoda, Y. Kihara, K. Fukumoto, Y. Sano and T. Hayashi, ACS Catal., 2014, 4, 2645-2648.

88 D. F. Sauer, T. Himiyama, K. Tachikawa, K. Fukumoto, A. Onoda, E. Mizohata, T. Inoue, M. Bocola, U. Schwaneberg, T. Hayashi and J. Okuda, ACS Catal., 2015, 5, 7519-7522.

89 F. Philippart, M. Arlt, S. Gotzen, S.-J. Tenne, M. Bocola, H.-H. Chen, L. Zhu, U. Schwaneberg and J. Okuda, Chem. - Eur. J., 2013, 19, 13865-13871.

90 H. Osseili, D. F. Sauer, K. Beckerle, M. Arlt, T. Himiyama, T. Polen, A. Onoda, U. Schwaneberg, T. Hayashi and J. Okuda, Beilstein J. Org. Chem., 2016, 12, 1314-1321.

91 A. Thiel, D. F. Sauer, M. A. S. Mertens, T. Polen, H. H. Chen, U. Schwaneberg and J. Okuda, Org. Biomol. Chem., 2018, 16, 5452-5456.

92 G. Roelfes, Acc. Chem. Res., 2019, 52, 545-556.

93 L. Villarino, K. E. Splan, E. Reddem, L. Alonso-Cotchico, C. Gutiérrez de Souza, A. Lledós, J.-D. Maréchal, A.-M. W. H. Thunnissen and G. Roelfes, Angew. Chem., Int. Ed., 2018, 57, 7785-7789.

94 H. Yang, P. Srivastava, C. Zhang and J. C. Lewis, ChemBioChem, $2014,15,223-227$.

95 P. Srivastava, H. Yang, K. Ellis-Guardiola and J. C. Lewis, Nat. Commun., 2015, 6, 7789.

96 H. Yang, A. M. Swartz, H. J. Park, P. Srivastava, K. Ellis-Guardiola, D. M. Upp, G. Lee, K. Belsare, Y. Gu, C. Zhang, R. E. Moellering and J. C. Lewis, Nat. Chem., 2018, 10, 318-324.

97 J. L. Beesley and D. N. Woolfson, Curr. Opin. Biotechnol, 2019, 58, 175-182.

98 O. Zozulia, M. A. Dolan and I. V. Korendovych, Chem. Soc. Rev., 2018, 47, 3621-3639.

99 T. B. J. Pinter, K. J. Koebke and V. L. Pecoraro, Angew. Chem., Int. Ed., 2020, 59, 7678-7699.

100 M. L. Zastrow, A. F. A. Peacock, J. A. Stuckey and V. L. Pecoraro, Nat. Chem., 2012, 4, 118-123.

101 A. E. Tolbert, C. S. Ervin, L. Ruckthong, T. J. Paul, V. M. JayasingheArachchige, K. P. Neupane, J. A. Stuckey, R. Prabhakar and V. L. Pecoraro, Nat. Chem., 2020, 12, 405-411.

102 M. Tegoni, F. Yu, M. Bersellini, J. E. Penner-Hahn and V. L. Pecoraro, Proc. Natl. Acad. Sci. U. S. A., 2012, 109, 21234-21239.

103 F. Yu, J. E. Penner-Hahn and V. L. Pecoraro, J. Am. Chem. Soc., 2013, 135, 18096-18107.

104 A. G. Tebo, T. B. J. Pinter, R. García-Serres, A. L. Speelman, C. Tard, O. Sénéque, G. Blondin, J.-M. Latour, J. Penner-Hahn, N. Lehnert and V. L. Pecoraro, Biochemistry, 2018, 57, 2308-2316.

105 D. Shiga, Y. Funahashi, H. Masuda, A. Kikuchi, M. Noda, S. Uchiyama, K. Fukui, K. Kanaori, K. Tajima, Y. Takano, H. Nakamura, M. Kamei and T. Tanaka, Biochemistry, 2012, 51, 7901-7907.

106 R. Sambasivan and Z. T. Ball, J. Am. Chem. Soc., 2010, 132, 9289-9291.

107 R. Sambasivan and Z. T. Ball, Angew. Chem. Int. Ed., 2012, 51, 8568-8572.

108 B. S. Der, M. Machius, M. J. Miley, J. L. Mills, T. Szyperski and B. Kuhlman, J. Am. Chem. Soc., 2012, 134, 375-385.

109 S. Studer, D. A. Hansen, Z. L. Pianowski, P. R. E. Mittl, A. Debon, S. L. Guffy, B. S. Der, B. Kuhlman and D. Hilvert, Science, 2018, 362, 1285-1288. 
110 R. L. Koder, J. L. R. Anderson, L. A. Solomon, K. S. Reddy, C. C. Moser and P. L. Dutton, Nature, 2009, 458, 305-309.

111 T. A. Farid, G. Kodali, L. A. Solomon, B. R. Lichtenstein, M. M. Sheehan, B. A. Fry, C. Bialas, N. M. Ennist, J. A. Siedlecki, Z. Zhao, M. A. Stetz, K. G. Valentine, J. L. R. Anderson, A. J. Wand, B. M. Discher, C. C. Moser and P. L. Dutton, Nat. Chem. Biol., 2013, 9, 826-833.

112 D. W. Watkins, J. M. X. Jenkins, K. J. Grayson, N. Wood, J. W. Steventon, K. K. Le Vay, M. I. Goodwin, A. S. Mullen, H. J. Bailey, M. P. Crump, F. MacMillan, A. J. Mulholland, G. Cameron, R. B. Sessions, S. Mann and J. L. R. Anderson, Nat. Commun., 2017, 8, 358.

113 E. N. Salgado, R. J. Radford and F. A. Tezcan, Acc. Chem. Res., 2010, 43, 661-672.

114 L. A. Churchfield and F. A. Tezcan, Acc. Chem. Res., 2019, 52, 345-355.

115 W. J. Song and F. A. Tezcan, Science, 2014, 346, 1525-1528.

116 J. Rittle, M. J. Field, M. T. Green and F. A. Tezcan, Nat. Chem., 2019, 11, 434-441.

117 W. J. Song, J. Yu and F. A. Tezcan, J. Am. Chem. Soc., 2017, 139, $16772-16779$.

118 A. J. Reig, M. M. Pires, R. A. Snyder, Y. Wu, H. Jo, D. W. Kulp, S. E. Butch, J. R. Calhoun, T. Szyperski, E. I. Solomon and W. F. DeGrado, Nat. Chem., 2012, 4, 900-906.

119 M. Faiella, C. Andreozzi, R. T. M. de Rosales, V. Pavone, O. Maglio, F. Nastri, W. F. DeGrado and A. Lombardi, Nat. Chem. Biol., 2009, $5,882-884$.

120 S.-Q. Zhang, M. Chino, L. Liu, Y. Tang, X. Hu, W. F. DeGrado and A. Lombardi, J. Am. Chem. Soc., 2018, 140, 1294-1304.

121 N. F. Polizzi, Y. Wu, T. Lemmin, A. M. Maxwell, S.-Q. Zhang, J. Rawson, D. N. Beratan, M. J. Therien and W. F. DeGrado, Nat. Chem., 2017, 9, 1157-1164.

122 N. H. Joh, T. Wang, M. P. Bhate, R. Acharya, Y. Wu, M. Grabe, M. Hong, G. Grigoryan and W. F. DeGrado, Science, 2014, 346, 1520-1524.

123 J. M. Perez-Aguilar and J. G. Saven, Structure, 2012, 20, 5-14.

124 A. Niitsu, J. W. Heal, K. Fauland, A. R. Thomson and D. N. Woolfson, Philos. Trans. R. Soc., B, 2017, 372, 20160213.

125 S. C. Patel and M. H. Hecht, Protein Eng., Des. Sel., 2012, 25, 445-452.

126 V. Nanda, M. M. Rosenblatt, A. Osyczka, H. Kono, Z. Getahun, P. L. Dutton, J. G. Saven and W. F. DeGrado, J. Am. Chem. Soc., 2005, 127, 5804-5805.

127 R. Bau, D. C. Rees, D. M. Kurtz Jr, R. A. Scott, H. Huang, M. W. W. Adams and M. K. Eidsness, J. Biol. Inorg. Chem., 1998, 3, 484-493.

128 A. D’Souza, M. Mahajan and S. Bhattacharjya, Chem. Sci., 2016, 7, 2563-2571.
129 C. M. Rufo, Y. S. Moroz, O. V. Moroz, J. Stöhr, T. A. Smith, X. Hu, W. F. DeGrado and I. V. Korendovych, Nat. Chem., 2014, 6, 303-309.

130 Z. Lengyel, C. M. Rufo, Y. S. Moroz, O. V. Makhlynets and I. V. Korendovych, ACS Catal., 2018, 8, 59-62.

131 P. Makam, S. S. R. K. C. Yamijala, K. Tao, L. J. W. Shimon, D. S. Eisenberg, M. R. Sawaya, B. M. Wong and E. Gazit, Nat. Catal., 2019, 2, 977-985.

132 A. R. Voet, H. Noguchi, C. Addy, K. Y. Zhang and J. R. Tame, Angew. Chem., Int. Ed., 2015, 54, 9857-9860.

133 Y. M. Wilson, M. Dürrenberger, E. S. Nogueira and T. R. Ward, J. Am. Chem. Soc., 2014, 136, 8928-8932.

134 Y. Okamoto, R. Kojima, F. Schwizer, E. Bartolami, T. Heinisch, S. Matile, M. Fussenegger and T. R. Ward, Nat. Commun., 2018, 9, 1943.

135 J. G. Rebelein, Y. Cotelle, B. Garabedian and T. R. Ward, ACS Catal., 2019, 9, 4173-4178.

136 W. Ghattas, V. Dubosclard, A. Wick, A. Bendelac, R. Guillot, R. Ricoux and J.-P. Mahy, J. Am. Chem. Soc., 2018, 140, 8756-8762.

137 E. L. Hegg and L. Q. Jr, Eur. J. Biochem., 1997, 250, 625-629.

138 K. D. Koehntop, J. P. Emerson and L. Que, J. Biol. Inorg. Chem., 2005, 10, 87-93.

139 B. Amrein, M. Schmid, G. Collet, P. Cuniasse, F. Gilardoni, F. P. Seebeck and T. R. Ward, Metallomics, 2012, 4, 379-388.

140 L. Zhou, M. Bosscher, C. Zhang, S. Ozçubukçu, L. Zhang, W. Zhang, C. J. Li, J. Liu, M. P. Jensen, L. Lai and C. He, Nat. Chem., 2014, 6, 236-241.

141 C. Aussignargues, M.-E. Pandelia, M. Sutter, J. S. Plegaria, J. Zarzycki, A. Turmo, J. Huang, D. C. Ducat, E. L. Hegg, B. R. Gibney and C. A. Kerfeld, J. Am. Chem. Soc., 2016, 138, 5262-5270.

142 S. R. Soltau, J. Niklas, P. D. Dahlberg, O. G. Poluektov, D. M. Tiede, K. L. Mulfort and L. M. Utschig, Chem. Commun., 2015, 51, 10628-10631.

143 G. G. Hammes, Biochemistry, 2002, 41, 8221-8228.

144 S. Hammes-Schiffer and S. J. Benkovic, Annu. Rev. Biochem., 2006, 75, 519-541.

145 J. L. Payne and A. Wagner, Nat. Rev. Genet., 2019, 20, 24-38.

146 M. A. Siddiq, G. K. Hochberg and J. W. Thornton, Curr. Opin. Struct. Biol., 2017, 47, 113-122.

147 B. E. Clifton, J. A. Kaczmarski, P. D. Carr, M. L. Gerth, N. Tokuriki and C. J. Jackson, Nat. Chem. Biol., 2018, 14, 542-547.

148 E. Wallin and G. V. Heijne, Protein Sci., 1998, 7, 1029-1038.

149 L. Fagerberg, K. Jonasson, G. Von Heijne, M. Uhlén and L. Berglund, Proteomics, 2010, 10, 1141-1149.

150 P.-S. Huang, S. E. Boyken and D. Baker, Nature, 2016, 537, 320-327.

151 N. M. Gallup and A. N. Alexandrova, in Methods in Enzymology, ed. G. A. Voth, Academic Press, 2016, vol. 577, pp. 319-339.

152 L. Alonso-Cotchico, J. Rodríguez-Guerra, A. Lledós and J.-D. Maréchal, Acc. Chem. Res., 2020, 53, 896-905. 